Université du Québec à Chicoutimi

\author{
MÉMOIRE \\ PRÉSENTÉ À \\ L'UNIVERSITÉ DU QUÉBEC À CHICOUTIMI \\ COMME EXIGENCE PARTIELLE \\ DE LA MAITRISE EN LETTRES
}

PAR GINETTE TREMBLAY

\title{
SELF-INTERPRETATION AND AGENCY IN SHAKESPEARE'S PROBLEM PLAYS
}

ÉTÉ 2012 


\section{ACKNOWLEDGEMENTS}

I would like to take this opportunity to offer my esteem and blessings to all those who supported me in any respect during the completion of my thesis project.

I would like to thank my family for supporting me through the difficult process that was the writing of this thesis. I appreciate their support.

I pay tribute to Mrs. Christiane Perron and to M. Mathew Benson for the help they provided in editing my work.

I would like to acknowledge the generosity of Marco Bacon and the team from the Centre des Premières Nations Nikanite for believing in me and providing me with a space to think and reflect. Their support was most precious.

I am indebted to my many friends and colleagues for their understanding, their constant encouragement, and support in various ways. I extend special acknowledgement to Mélissa Lapointe, Jean-Philippe Pouliot, and Jonny Perron for sharing their experience and ideas during my difficult episodes. Natalie and Robert, you are in my heart.

Last but not least, my utmost and deepest gratitude is conveyed to my supervisor, Professor Mustapha Fahmi whose charismatic passion sparked and nurtured my intellectual 
maturity. His great knowledge has been an unfailing source of inspiration. As the instigator of my passion for ethics and Shakespeare, he has been the backbone of my project. His perspicacity and sensibility have sustained me through the most trying, difficult times as those one is faced to when writing such a piece of work. His advice and guidance have always proven to be most valuable and beneficial. His patience, humanity, and generosity place him in a class of his own. He is for me a guide, a mentor, a friend to whom I am forever indebted. 


\section{Self-Interpretation, Character and Agency in Shakespeare's Problem Plays}

Self-interpretation - the way human agents define themselves through a language of articulacy - is what my paper is about. I want to suggest, through a reading of Measure for Measure, All's Well That Ends Well, and Troilus and Cressida, that Shakespearean characters articulate their identities by being oriented toward what they contemplate as the higher good. My purpose is to demonstrate how Isabella, Bertram, and Hector's definitions of themselves influence their decisions and thus their actions. In the light of Charles Taylor's writings linking self-interpretation and ethics, I will examine the development of each character's identity in terms of what she or he considers as the ultimate life, more specifically and respectively the life of a virgin, the life of a soldier, and the life of a proud and famous leader. For Taylor, self-interpretation is shaped by the pursuit of a certain good deemed higher than the others. I also specifically draw on Mustapha Fahmi's particular views proposing that self-interpretation is one of the underlying conditions of agency in Shakespeare. Fahmi affirms that Shakespeare's characters are self-interpreting subjects; the way they define themselves is the scaffolding upon which their identity is constructed. Agents such as Isabella, Bertram, and Hector seem to act out of a certain assurance that the good they strive for is not only worthier and higher than all others, but more likely to lead 
them to happiness. All three characters have the capacity to make evaluations based on distinctions of worth.

Les personnages de Shakespeare sont des sujets auto-interprétateurs, c'est-à-dire que la façon dont ils se définissent est l'échafaudage sur lequel est construite leur identité ${ }^{1}$. L'auto-interprétation, définie par Mustapha Fahmi comme étant la manière par laquelle l'agent se donne sens à travers un langage d'expressions riches, est le sujet de mon mémoire. C'est en prenant appui sur les écrits de Mustapha Fahmi sur l'auto-interprétation que sera examiné le développement identitaire de Isabella de Measure for Measure, de Bertram de All's Well that Ends Well et de Hector de Troilus and Cressida. J'aurai aussi recours aux recherches du philosophe Charles Taylor pour sa vision particulière qui lie l'auto-interprétation et l'éthique. Pour Taylor, l'auto-interprétation est façonnée par la poursuite d'un « bien » estimé supérieur aux autres. Or, la capacité à évaluer des biens est le critère sous-jacent de l'agentivité dans les œuvres de Shakespeare. Comme nous pourrons le voir dans les trois pièces ci-haut mentionnées, Isabella, Bertram et Hector sont des agents dans le sens où ils agissent selon certains critères à savoir que le bien qu'ils poursuivent est non seulement supérieur aux autres biens, mais aussi enclin à les mener vers le bonheur.

\footnotetext{
${ }^{1}$ FAHMI, Mustapha, The Purpose of Playing: Self-Interpretation and Ethics in Shakespeare, Québec: Two Continents Publishing, p. 13, 2008.
} 


\section{Table des matières}

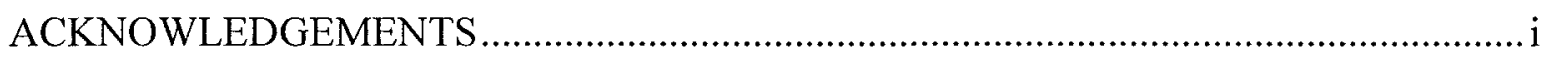

Self-Interpretation, Character and Agency in Shakespeare's Problem Plays .................... iiiii

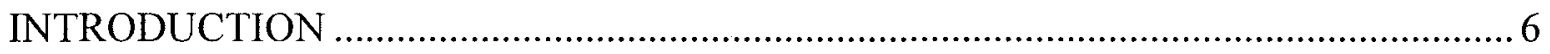

"...More Than our Brother Is our Chastity" Self-interpretation and Chastity in

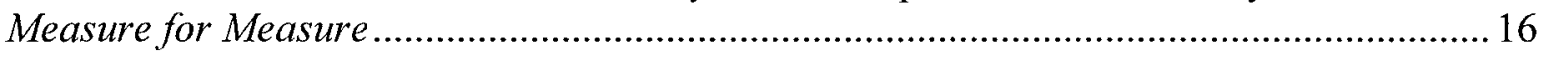

"To-morrow I'll to Wars, She to her Single Sorrow" Self-Interpretation and Honor in All's Well that Ends Well................................................................................... 40

"Mine Honour Keeps the Weather of my Fate" Self-Interpretation and Fame

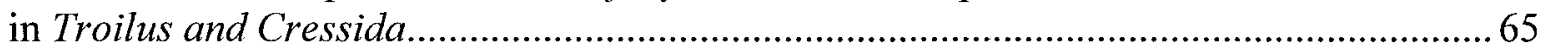

CONCLUSION

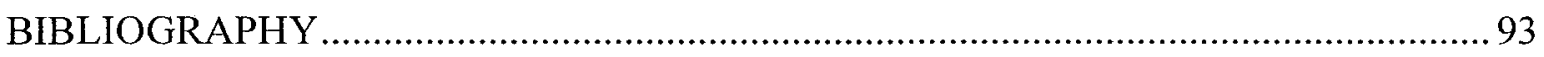




\section{INTRODUCTION}

Between 1601 and 1605, William Shakespeare wrote a group of three plays commonly known as the "problem plays". These plays show a distinct cleavage from his previous comedies and tragedies. They differ from the others in the way their action focuses on problematical ethical questions which prove difficult to address within a comical structure. Their strangeness is such that it was not until 1896 that a more distinct definition was suggested by F.S. Boa, the same definition applied to the plays of Shaw and Ibsen, namely 'problem plays':

All these dramas introduce us into highly artificial societies, whose civilization is ripe unto rottenness. Amidst such media abnormal conditions of brain and of emotion are generated, and intricate cases of conscience demand a solution by unprecedented methods. Thus throughout these plays we move along dim untrodden paths, and at the close our feeling is neither of simple joy nor pain; we are excited, fascinated, perplexed, for the issues raised preclude a completely satisfactory outcome, even when, as in All's Well and Measure for Measure, the complications are outwardly adjusted in the fifth act. In Troilus and Cressida... no such partial settlement of difficulties takes place, and we are left to interpret their enigmas as best we may. Dramas so singular in theme and temper cannot be strictly called comedies or tragedies. We may therefore borrow a convenient phrase from the theater of today and class them together as Shakespeare's problem-plays. $^{2}$

This definition well renders the essence of these particular plays 'presenting no transcript from life ${ }^{3}$, where complications of existence are depicted and where no clear and

\footnotetext{
${ }^{2}$ F.S. Boa in Vivian Thomas, The Moral Universe of Shakespeare's Problem Plays ( NJ: Barnes \& Noble Books, 1987). p. 3.

${ }^{3}$ Thomas, The Moral Universe of Shakespeare's Problem Plays. p. 5.
} 
precise solution is offered. It is evidently not surprising that they barely had any effect on the Renaissance general public, who simply could not relate to them. A recent renewal of interest in modern audiences and critics for the problem plays has been noted. The 'highly artificial societies and civilizations ripped unto rottenness ${ }^{4}$, depicted in the problem plays as the social matters treated in them seem to find echo in the complexity of modern times. These plays are delivered in a way that, not only trigger interest or emotion from the modern audience, but also fathom the intricate questions on correlation between the characters, the way they see themselves, and the way their actions in contexts open to a multitude of moral interpretations.

My interest in these plays is limited to the main characters' capacity to act. Isabella, Bertram, and Hector are caught in situations where they are confronted with a difficult choice between opposite principles. The chosen option is always the most controversial. What pushes Isabella to prefer her chastity to her brother's life? Why does Bertram prefer the dangers of war to the comfort of matrimonial life? What incites Hector to endanger the life of thousands of Trojans in the name of honor? The purpose of this thesis is to provide an answer to these questions. I would like to argue that the main characters of these plays develop a sense of who they are and articulate an identity by being oriented towards what they consider their ultimate $\operatorname{good}^{5}$.

In order to do so, I draw on the work of Mustapha Fahmi, especially his reading of Shakespearean characters as self-interpreting subjects. In The Purpose of Playing: SelfInterpretation and Ethics in Shakespeare, Fahmi claims that self-interpretation is an

\footnotetext{
${ }^{4}$ F.S. Boa in Thomas, The Moral Universe of Shakespeare's Problem Plays. p. 3.

${ }^{5}$ Mustapha Fahmi, Shakespeare's Poetic Wisdom: Identity, Orientation, and Historical Providence in the Henriad (Cap-Rouge: Two Continents Publishing, 2003). p. 14.
} 
approach through which the Shakespearian character makes sense of self through a language of articulacy ${ }^{6}$. Shakespearian characters are self-interpreting subjects in the sense that the way they define themselves shapes their actions and the choices they make. The concept of self-interpretation elaborated by Professor Fahmi is inspired by Friedrich Nietzsche's work, more specifically his definition of interpretation as an introduction of sense, and by the work of Canadian philosopher Charles Taylor and the link he establishes between hermeneutics and ethics.

Between the essentialist approach granting the Shakespearian character complete autonomy and freedom of choice and action and the "New historicist" approach denying agency to the character, Fahmi takes an Aristotelian position between the two extremes: those who, like new historicists, maintain that Shakespeare has not invented his characters or anything else for that matter, and those who, like Harold Bloom, allege that Shakespeare as the inventor of the human?

For new historicists, Shakespearean characters are cultural products shaped by the changing social surroundings of their era. For that reason, new historicists deny Shakespearean characters all human abilities such as imagination and autonomy. They view them as the depiction of individuals who are themselves subjects of their own culture and times. As a result, Shakespeare's characters cannot be considered as archetypes of standard human nature.

\footnotetext{
${ }^{6}$ Mustapha Fahmi, The Purpose of Playing: Self-Interpretation and Ethics in Shakespeare (Québec: Two Continents Publishing, 2008).

${ }^{7}$ Mustapha Fahmi, "Man's Chief Good: The Shakespearean Character as Evaluator," The Shakespearean International Yearbook, eds. Graham Bradshaw and Tom Bishop, vol. 8 (Hampshire, England: Ashgate, 2008). p. 120.
} 
On the opposite end, Harold Bloom takes on a whole different perspective on the matter. For him, Shakespeare is not just the creator of the English language; he is also the inventor of human nature as we understand it in our modern world ${ }^{8}$. Bloom explains that before Shakespeare, characters were defined merely through narratives in which their characteristics and main features were described by authors. After Shakespeare, they become "self-hearing" entities, capable of introspection. They undergo changes through "self-overhearing", a term to describe "a sudden insight into one's own consciousness....a certain dialogue, sometimes with oneself and sometimes with others ${ }^{9 "}$.

As intuitive as Bloom's concept may be, it unintentionally disregards Charles Taylor's contribution pertaining to the construction of one's identity. For Taylor, the capacity to evaluate and the importance of otherness have a crucial impact on the elaboration of identity. First of all, for Bloom, there is "dialogue at times with oneself, at times with others, and Shakespearean characters undergo changes by overhearing themselves speaking to others ${ }^{10 "}$. The difference between Bloom's concept and Taylor's lies in the importance of otherness. Taylor's argument on the subject emphasizes the "dialogical nature of people" as the significance and impact of otherness in the construction of identity in human beings as in literary characters ${ }^{11}$. He maintains that individuals, as Shakespearean characters, articulate an identity "through a continuous exchange with other people, real or imaginary, especially those whose views matter to us, whether they are

\footnotetext{
${ }^{8}$ Harold Bloom, Shakespeare: The Invention of the Human (New York, NY: Riverhead Books, 1998).

'Fahmi, "Man's Chief Good: The Shakespearean Character as Evaluator." p. 121.

${ }^{10}$ Fahmi, "Man's Chief Good: The Shakespearean Character as Evaluator." p. 121.

${ }^{11}$ Charles Taylor, The Malaise of Modernity (Concord: Anansi, 1996). p. 33.
} 
friends or foes ${ }^{12 \%}$. Thus, the dialogic character of the human and the importance of otherness play a prominent role in the elaboration of identity for human beings as for literary characters. The term "dialogue" in itself suggests that there is an exchange of ideas through language and is always taking place between two interlocutors or more, real or imaginary. Pertaining to this, Taylor argues that "language only exists and is maintained within a language community and, because of this, individuals become selves among other selves. And so, a self can never be described without reference to those who surround it ${ }^{13}$." In fact, individuals find the answer to the question "who am I" through conversations and discussions with others. They define and position their selves within the place where the exchanges and communication take place: family unit, social space, social status and functions, or those with whom they are more intimately and affectively involved. These relations are crucial in the elaboration of the moral space or framework and ethical discernment, as they are in the development of a "language of articulacy", a language used to articulate an identity. Without these relations, the definition of the self is unthinkable.

Likewise, the importance of what makes life worth living and the capacity to choose also influences the definition of moral boundaries, or what Taylor calls "background picture" or "framework", within which the individual may explain or make sense of ethical discernment and the evaluation benchmarks for morality. This concept not only suggests that the choices are made in relation with what is valuable and worthy for an individual, but also that the choices made are evaluated within a hierarchy of goods, what Taylor describes

\footnotetext{
${ }^{12}$ Mustapha Fahmi, "Quoting the Enemy: Character, Self-Interpretation, and the Question of Perspective," Shakespeare and Moral Agency, ed. Michael Bristol, D. (London: The Continuum International Publishing Group, 2010). p. 132.

${ }^{13}$ Charles Taylor, Sources of the Self: The Making of the Modern Identity (Cambridge: Hardvard University Press, 1989). p. 35.
} 
as "strong or weak evaluations" where one estimates possible choices based on ethical appraisal or on mere desire ${ }^{14}$ :

Our identity is therefore defined by certain evaluations which are inseparable from ourselves as agents. Shorn of these we would cease to be ourselves, by which we do not mean trivially that we would be different in the sense of having some properties other than those we now have... but that shorn of these we would lose the very possibility of being an agent who evaluates; that our existence as persons, and hence our ability to adhere as persons to certain evaluations, would be impossible outside the horizon of these essential evaluations... To lose this horizon, or not to have found it, is indeed a terrifying experience of disaggregation and loss ${ }^{15}$.

Thus, the capacity to choose, to evaluate, and otherness are interweaved elements of the "moral framework" and are capital in the construction of identity.

From the above theories, Mustapha Fahmi extends his character criticism one step beyond. In her article "What's Virtue Got to Do with It?" Sarah Goodin says:

Although there may be nothing particularly novel in the notion that man is a political animal, the emergence of this idea within the recent literary critical approach to character outlined by Mustapha Fahmi does represent a noteworthy development ${ }^{16}$.

Fahmi proposes the idea that agency in the Shakespearean character is closely associated with the Taylorian concept of "strong evaluations" in the sense that "the character's identity is determined by what is of crucial importance for him or her ${ }^{17}$." Indeed, Fahmi proposes self-interpretation as the manner in which human agents make sense of themselves through

\footnotetext{
${ }^{14}$ Fahmi, "Man's Chief Good: The Shakespearean Character as Evaluator." p. 123.

${ }^{15}$ Charles Taylor, Human Agency and Language: Philosophical Papers (Cambridge: Cambridge University Press, 1999). p. 34-35.

${ }^{16}$ Michael Bristol, D., ed., Shakespeare and Moral Agency (London: The Continuum International Publishing Group, 2010). p. 184-199.

${ }^{17}$ Fahmi, "Man's Chief Good: The Shakespearean Character as Evaluator." p. 123.
} 
a language of articulacy ${ }^{18}$. He argues that Shakespearean characters shape their identities and become who they are through dialogues and interaction with those who matter to them. In his view, Shakespearean characters are full constituents of the society surrounding them and take action within situations in regards to their own moral conceptions. Selfinterpretation is provided by the culture of an era, through society, through literature ${ }^{19}$.

Professor Fahmi denounces the tendency of conventional criticism to analyse literary characters in the light of the action they take or fail to take. An action as such cannot be perceived as good or bad, as wise or illogical, important or derisory. It is an illusion if it is evaluated without considering human interpretation. In fact, when we judge an action, we reveal more of ourselves than we do of the action ${ }^{20}$. It is in this view that Fahmi suggests a new approach to character, one founded on ethical orientation that motivates the action. Consequently, in order to be plausible, such criticism must take in consideration human characteristics such as comprehension and interpretation of the self. The perception of self is elaborated from dialogues or discussions with the significant other, whether it be friend or enemy, real or imaginary ${ }^{21}$. Hence, as we will see, Shakespearian characters become human agents because they are engaged in continuous dialogues with those who are important to them.

Professor Fahmi maintains that everything a character says or does not say, everything he does or does not do contributes in great part to the conception of the image this character has of himself ${ }^{22}$. The discussions circulating about the chosen characters, as

\footnotetext{
${ }^{18}$ Fahmi, The Purpose of Playing: Self-Interpretation and Ethics in Shakespeare.p. 13.

${ }^{19}$ Fahmi, The Purpose of Playing: Self-Interpretation and Ethics in Shakespeare. p. 25.

${ }^{20}$ Ibid. p. 23.

${ }^{21}$ Ibid. p. 13.

22 Ibid. p. 13.
} 
the dialogues diffused around them, do have an impact on these. However, to be able to position oneself in relation to the interpretation of oneself implies the possession of capacity to make moral choices, to prefer some criteria to others for ethical reasons. M. Fahmi establishes a connection between his vision of self-interpretation and Charles Taylor's concept of identity. In Sources of the Self $f^{23}$, Taylor argues that an individual who conceives himself according to his principles, has, indubitably, defined what he esteems as his "superior good", a good he judges as the ultimate factor symbolizing the quintessence of his happiness. Self-interpretation of Shakespearian characters is then founded and oriented toward what they view as their "ultimate good". Nevertheless, to be able to take a position in a delimited moral framework, the individual must have established, a priori, an image of himself.

In other words, a character's capacity to act is determined by what is crucial to him. Even if the character's conception of himself is wrong, the way he defines it is, theoretically, the foundation upon which his identity is edified ${ }^{24}$. Whether an external point of view is more valid than the character's choice does not change the fact that it is the character's perception of himself that counts and allows us to understand his actions. Self interpretation does not have to be approved by all to be significant. What is essential here is not others' questioning in relation to who we are, but their questioning as to whom we want to be, or the role that we strive to play on the great theater of life $\mathrm{e}^{25}$.

The main objective of this thesis is to show that the choices made by the characters may be understood if the "background of intelligibility from which the character determines what is good or bad, what is to be done or not, ${ }^{26}$, is taken into consideration. In

\footnotetext{
${ }^{23}$ Taylor, Sources of the Self: The Making of the Modern Identity.

${ }^{24}$ Fahmi, The Purpose of Playing: Self-Interpretation and Ethics in Shakespeare. p. 24.

${ }^{25}$ Ibid. p. 25.

${ }^{26}$ Fahmi, The Purpose of Playing: Self-Interpretation and Ethics in Shakespeare. p. 13.
} 
other words, I will attempt to show and analyze the main characters of these problem plays not from my perspective, but rather from the way they perceive themselves. Just like the protagonists of the Henriad (Richard II, Hotspur, and Henry V) or like heroes of the Roman tragedies (Caesar, Brutus, Antony and Cleopatra) which Mustapha Fahmi defines as "selfinterpreting subjects ${ }^{27}$, the protagonists of the "Problem plays", Isabella, Bertram, and Hector are, equally, agents who interpret and define themselves through a language of articulacy. Everything they do or not do, everything they say or not say contributes in great part to shape the image they have of themselves ${ }^{28}$. However, as Professor Fahmi has already mentioned in his works on Shakespeare, works inspired by Nietzsche and Charles Taylor, Self-Interpretation is inconceivable in an ethical void. Shakespearean characters give a sense and interpret themselves in reference to a good they consider superior to others.

The capacity to evaluate good is one of the underlying conditions of agency in Shakespeare. Agents, [...] who possess a strong sense of who they are, seem to act out of a certain conviction that the good they pursue is not only higher and worthier than other goods, but also more likely to lead them to happiness. Conversely, human patients [...] tend to act under the impress of immediate desire, often against their own better judgement. They may have will, determination, and reflection, but they lack the ability to make evaluations based on distinctions of worth. $^{29}$

The good that the characters of the Problem Plays strive to pursue is honor. As the key-concept of this thesis, honor will allow us to demystify in part the identity of the chosen characters of this study as well as the object of motivation of their actions, whether these are appropriate or not.

\footnotetext{
${ }^{27}$ Ibid. p. 13.

${ }^{28}$ Ibid. p. 13.

${ }^{29}$ Fahmi, The Purpose of Playing: Self-Interpretation and Ethics in Shakespeare. p. 14.
} 
Accordingly, it is under a biblical cover that Measure for Measure addresses misuse of power and gender inequality, as does All's Well That Ends Well with social hierarchy and complicated interrelationships. As for Troilus and Cressida, it is concerned with themes such as the absurdity of war, sexuality and treason. Even if these plays are viewed as comedies, the fact remains that their conclusion does leave audiences in a state of perplexity. In most cases, comedies suggest a theatrical conclusion of happiness and of nuptial celebrations, to the characters and the audience's satisfaction. Yet, two of the "Problem Plays" end in marriage, but show ambiguity with respect to their happy conclusions. As for Troilus and Cressida, it cannot be defined as a comedy, tragedy, or historical drama, although it contains constituents of the three genres.

Isabella, Bertram, and Hector are Shakespearean characters for whom "the notion of honor is so crucial to their self-interpretation ${ }^{30}$ " that they will go to extremes to save their ideals and pursue their own "higher good". By applying these concepts to them, my goal is to show that these Shakespearian heroes are, in fact, authors of their own identities.

\footnotetext{
${ }^{30}$ Ibid. p. 60.
} 


\section{CHAPTER I}

"Virtus Vera Nobilita Est"

Latin Proverb

(Virtue is true nobility)

\section{"... More than our brother is our chastity" Self-interpretation and Chastity in Measure for Measure}

If great plays were meant to provoke strong reactions from audiences, then Measure for Measure would be a sure contender for the "most provocative of Shakespeare's entire work" award. Its unusual plot and unconventional dramatis personae surely make it a source of critical divergence among scholars of all times.

Measure for Measure $e^{32}$, presumably the last of the "problem plays," is thought to have been written in late 1603 and was first performed on December $26^{\text {th }}$ of that same year for the newly enthroned King James I. Very few comedies were written during this particular period, and the comedies that were written were different from the joyous, cheerful comedies of the $1590^{\prime}$ s. As in all of Shakespeare's plays, Measure for Measure addresses concerns of the age. The questions of religious doctrine, abuse of power, sexual decadence - as the questions of gender roles - and male supremacy revealed in this

\footnotetext{
${ }^{31}$ Shakespeare, "Measure for Measure," The Complete Works of Shakespeare, ed. David Bevington (New York: Pearson Longman, 2004).

${ }^{32}$ Shakespeare, "Measure for Measure."
} 
problematic comedy confirm a complex reflection on its own epoch's obscure side of human reality, a side still very valid today. These themes set the action and move the play into the tragic/comic ambiguity that bewilders both audiences and experts. Nearly all aspects of Measure for Measure are subjects for dispute in criticism. For John Dryden, the play is "meanly written that the Comedy neither caus'd your mirth, nor the serious part your concernment ${ }^{33 ",}$. In a similar way, $\mathrm{S}$. T. Coleridge sees it as "the single exception to the delightfulness of Shakespeare's plays. (.....) a hateful work although Shakespearian

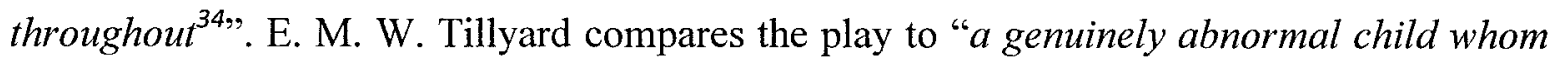
no efforts will ever bring back to normality ${ }^{35, "}$. More recently, Charlotte R. Lennox who defines it as being "disordered and ethically incoherent" ${ }^{36 "}$ definitely sets Measure for Measure as, in Keats' words, "...a thoroughfare for all thoughts".

This "comedy" takes place in Renaissance Vienna. The subject matter seems rather simple: Isabella, a young novice, comes to implore Angelo, a magistrate, to spare the life of her brother Claudio who is sentenced to death. The magistrate states that he will spare his life if she submits to the magistrate sexually. However,, the scenario hovering around the story is more intricate. The Duke of Vienna, a clement and permissive character, rules over a city that is tainted with solecism, depravity, and immorality. Corruption and sex are a lifestyle in this society. The dilemma here is, without a doubt, moral and social; that is, foul corruption stemming from concupiscence and misapplication of legal authority, as vividly portrayed by the Duke: “... My business in this state made me a looker-on here in Vienna,

\footnotetext{
${ }^{33}$ Brian Vickers, Shakespeare: The Critical Heritage. 1623-1692, vol. 1 (London: 1974). p. 145.

${ }^{34}$ S.T. Coleridge, Coleridge's Criticism of Shakespeare (Continuum International Publishing Group, 1989). p. 178.

${ }^{35}$ E.M. Tillyard, Shakespeare's Problem Plays (Toronto: Toronto University Press, 1971). p. 2.

${ }^{36}$ R. P. Wheeler, Critical Essays on Shakespeare's Measure for Measure (G.K. Hall \& Co., 1999). p. 2.
} 
where I have seen corruption boil and bubble till it o'errun the stew" (V.i: 315-318). Not only is the city undermined by laxity, but justice and sanctions against violating the law are inconsistent and disproportionate as well. In Measure for Measure, disparity is an evident feature both in the importance of the crimes and in the punishment imposed consequently.

According to the Aristotelian conception of state, ${ }^{37}$ a state need be virtuous in concordance to the virtue of the social body composing it, the play's society is in concordance with chaotic Vienna. Furthermore, the characters are also prompts for dissension. Measure for Measure is a touchstone of contention in the way Shakespeare handles the virtues and vices of the human mind, most noticeably in situations where the characters are entrapped and need to make difficult choices between opposing principles. Moreover, the choice made always seems steeped in controversy. Among the characters of the play, Isabella has generated the most interrogations by her unusual behaviour. For sure, she does not leave anybody indifferent. She is thought of as a "paragon of chastity" by some and an insensible creature "lacking human feelings" 38 " by others. Harold Bloom claims that Isabella is "the most problematical in this most problematic of all of Shakespeare's play ${ }^{39}$ ". The one point that seems to be the predominant source of annoyance among both critics and audiences is the choice made by Isabella when she is requested to save her brother's life. Why does Isabella choose to favour her chastity over

\footnotetext{
${ }^{37}$ Aristotle cited in M. Foucault, Histoire De La Sexualité Ii: L'usage Des Plaisirs (France: Éditions Gallimard, 1984). p. 107.

Aristotle's conception of a virtuous state is articulated in the following manner; a state is virtuous due to the fact that its citizens participating to its governing are themselves virtuous....that, even if the whole community of citizens are virtuous without any of them being so individually, it is nonetheless individual virtue that is to be preferred because the virtue of the whole social body (the state) follows logically the virtue of each individual. (my translation)

${ }^{38}$ I Kamps, Raber, K, Measure for Measure: Texts and Contexts (Boston: Bedford/ St-Martin's, 2004$)$. p. 194.

${ }^{39}$ Harold Bloom, Modern Critical Interpretation: William Shakespeare's Measure for Measure (New York: Chelsea House Publishing, 1987). p. 1.
} 
her own brother's life? The purpose of this chapter is to propose an answer to this controversial question by showing how Isabella defines her identity through honour, a key concept of her epoch, and the influence it has not only her decisions but also on her actions and, consequently, on why she views chastity as her means to happiness.

To get a full scope of Isabella's motivations some questions must be taken to account: What determines Isabella's sense of worth of life? What kind of life does she want to live in relation to her definition of the good? The answers to these questions will provide, partly, the arguments influencing Isabella's actions. In fact, "Shakespeare's major characters get a strong sense of who they are and articulate an identity by being oriented toward what they regard as the good life ${ }^{40,}$ and thus, Isabella definitely knows what she regards as her ultimate good and what needs to be done to reach it. In Measure for Measure, as in all of Shakespeare's work, the social principles of the era cannot to be ignored. Here, honour is the concept clearly and repeatedly stressed and emphasized in different forms throughout the text. In Shakespearean England, honour is the influential precept fashioning philosophy. The notion of honour then is not so different from the one found in Aristotle ${ }^{41}$. For both concepts, honour is the result of virtue. According to Aristotle, honour is defined as " $\ldots$ ys $a$ certeine testemonie of Vertue shining of yt self, given of some man by the judgement of good men... 42 ". Thus, honour is demonstrating respect for one's fellow human beings,

${ }^{40}$ Fahmi, Shakespeare's Poetic Wisdom: Identity, Orientation, and Historical Providence in the Henriad. p. 14.

${ }^{41}$ C. Brown Watson, Shakespeare and the Renaissance Concept of Honor (New Jersey: Princeton University Press, 1960). p. 10.

${ }^{42}$ Robert Ashley in Norman Council, When Honor's at the Stake: Ideas of Honor in Shakespeare's Plays (London: Harper \& Row 1973). p. 15.

English Renaissance was strongly influenced by Christianity and atheist theorists of classical antiquity which precepts are both aimed towards the same direction: virtue and honor. They are complexly intertwined. England courts were governed by the church. The fact that the king was the religious authority as well as the 
regardless of their social status. Also implied in the respect for others is to respect others with no thought whatsoever for self-interest. In his book When Honour is at the Stake, Norman Council states that "a man who performs a virtuous act is rewarded with honour, both of reputation and in the quite tangible form of preferment to a superior position, award of lands, or the like. ${ }^{43}$ " Material gains obtained from providing an external sample of inner distinction or value is interesting in itself, but during the Renaissance, intangible dividends are most sought after. Without doubt, the importance of peer perception - a crucial element to the establishment of a good reputation - is the most appealing of rewards ${ }^{44}$. For people then, this reward did not resume to a simple due given for any sort of action. As Council's statement above shows, it was an utterly coveted prize for display of virtuous acts ${ }^{45}$, deeds accomplished on standards of goodness, duty, and moral rectitude. One is seen by his or her peers is a gift transcending beyond generations, beyond life itself, as demonstrated by Lucio:

Lucio: ...I hold you as a thing enskied and sainted, By your renouncement an immortal spirit,

political leader shows its extensive presence. Greek philosophy coincides with the religious values influencing Renaissance, a period during which an attempt is made to join together two distinct systems of value: Christianity and pagan humanism.

For the Renaissance population, it is fundamental, not to say sacred, to achieve simultaneously one's responsibilities towards religion as moral commitments originating from the code of honor.

${ }^{43}$ Council, When Honor's at the Stake: Ideas of Honor in Shakespeare's Plays. p. 15.

${ }^{44}$ SHALVI, A., The Relationship of Renaissance Concepts of Honour to Shakespeare's Problem Plays, Salzburg, Universitat Salzburg, 1972, p. 35.

The author enumerates different definitions for the word "honor" emphasizing the complexity of its meaning. The definitions are presented under four divisions: First, honor referring to material (social rank, material wealth) and immaterial worth (reputation, fame, glory). Second, specific deeds or actions' leading to a person's honouring (military deeds or chaste conduct for women). Third, honor as inner awareness, enticing someone to perform acts leading to peer-esteem, and fourth, honour as "code of honour", a combination of the second and third meanings of honor. It constituted the standards of social behaviour and living during Renaissance.

45 Virtue, based on Aristotle's premises, is considered an innate concept as would instinct. It is a natural, unwavering state of character that cannot be accounted for as ability or a passion. A virtuous person was one who displayed a disposition to stable character traits. 
And to be talked with in sincerity, As with a saint.

(I.iv: $33-37$ )

Showers of appreciation from her contemporaries pertaining to honour appear on several occasions throughout the play: "... She, having the truth of honor in her..." (III.i: 159-164). Isabella surely enjoys a good reputation. Others not only think of her as virtuous, they also praise and promote her worth with no restrain:

\author{
Servant: Here is the sister of the man condemned \\ Desires access to you. \\ Angelo: Hath he a sister? \\ Provost: Ay, my good lord, a very virtuous maid, \\ And to be shortly of a sisterhood, \\ If not already.
}

(II.ii: 43-47)

She is endowed with this sense of goodness, duty, and moral rectitude in reputation and in character, as defined by Aristotle. According to Aristotle, moral character is defined as excellence of character as a state concerned with choice, lying in a mean relative to each individual, determined by reason and in the way the man of practical wisdom would determine it. She is one who possesses such character ${ }^{46}$. She is instinctively inclined towards righteousness and has a faculty for loyalty pertaining to it. To fully grasp Isabella's identity, and thus understand her actions, it is crucial to keep in mind that "we do not invent our way of defining ourselves. Self-interpretations are generally made available to us by

\footnotetext{
${ }^{46}$ Aristotle, The Nicomachean Ethics (New York: Oxford University Press, 1980). p. 41. (1106b36-1107a3)
} 
our culture, and are developed in interaction with other people ${ }^{47 \%}$. Due to her religious status, Isabella knows that she is expected to be virtuous, and capable of carrying out the virtuous acts expected of her. To be praised as such surely impacts Isabella's own interpretation of honour and makes it fundamental on both a private and public point of view.

Accordingly, she is bound to prove worthy of these praises. Isabella is immaculate reputation-wise and, even though the fact that she is part of a religious order accentuates her distinction, it is not the only factor explaining her preference for chastity. The influence religion has on people and their precepts during the Renaissance surely weigh on the way Isabella sculpts her identity. To Isabella, her status as a nun provides a retreat from society, and hiding in the comfort of a nunnery, and hiding from reality as a whole is the modus operandi pledging total preservation of her chastity:

Isabella: And have you nuns no farther privileges?

Nun: Are not these large enough?

Isabella: Yes, truly. I speak not as desiring more,

But rather wishing a more strict restraint

Upon the sisterhood, the votarists of Saint Clare.

(I.iv: $1-5)$

Being a novice about to pronounce her vows most certainly influences Isabella in the selection of her self-defining motives. Since prayer and the reading of the Bible are part of her daily duties, she surely must have been apprised of its content. The Bible is very explicit when it comes to fornication. It clearly states that premarital intercourse, - and

\footnotetext{
${ }^{47}$ Fahmi, The Purpose of Playing: Self-Interpretation and Ethics in Shakespeare. p. 24.
} 
adultery in this instance - is a sternly forbidden and condemned act ${ }^{48}$. With her sense of righteousness, Isabella can only be sensible to these words. Another interesting point also appearing in the Bible and unquestionably known by Isabella is found in the Ten Commandments (Exodus 20: 2-17). Two of these commandments refer directly to the consequences of fornication $^{49}$.

In a similar way, the young novice would surely have been conscious in reference to the Mortal $\operatorname{sins}^{50}$. Isabella is part of the Votaries of St-Clare, a Catholic religious congregation. Since Mortal sins are among the first religious precepts taught to the commonest of Catholics, she surely would have been aware of their content and of the warning given by Jesus stating that "anyone who does not remain in me will be thrown out like a branch and wither; people will gather them and throw them into a fire and they will be burned" (John 15:6). With her status, in position and in reputation, Isabella surely would not put herself in a state of mortal sin and risk eternal damnation. These most certainly are fundamental elements of Isabella's self-fashioning, and they serve her well in her quest of protection of chastity.

Even though Isabella's aspiration to enter the sisterhood surely involves a refractory refusal of the lifestyle of her society and patriarchal oppression, she nonetheless acts for her

\footnotetext{
${ }^{48}$ New Testament (Matt. 5:32; 19:9; John 8:41; Rom. 1:29; 1 Cor 5:1, 6:13, 18, 7:2; 10:8; 2 Cor 12:21; Col 3:5; Jude 1:7)

49 "Honour your father and mother" (respectus parentelae) could be interpreted as an early claim against incest. "You shall not commit adultery" very clearly condemns intimate relations between a married person and another other that the lawful spouse. Again, in Measure for Measure, Elbow specifically mentions it as a criminal, reprehensible act (II.I: 77-78).

${ }^{50}$ Mortal sins are the ones destroying God's Holy grace in the Christians' hearts and souls. They are believed to stray them away from their creator. They are committed in full awareness and premeditation. They are defined as "knowledge of the truth" as observed by St-Paul in his letter to the Hebrews: "...if we sin wilfully after having the knowledge of the truth, there is now left no sacrifice for sins" (Hebrews 10:26). Among these sins are adultery, fornication and uncleanness.
} 
fundamental beliefs and choices. Her profound principles supersede all physical desires. She disapproves of the chaotic lifestyle and debauchery prevailing in Vienna. Her turning to religion is an expedient towards purity and moral uprightness in spite of the fact that fornication and depravation are common behaviours in her times. For her, the only way of achieving virtuousness is by raising chastity above all other virtues. (Measure for Measure was written under the pretence of religion of the middle Ages, and consequently, addresses a sense of morality, respect, integrity, nobility, terms which happen to amalgamate into one single word, "honour".)

Another point should be taken into account to understand Isabella's actions: the conception of feminine honour. Here, honour pertaining to gender crucially influences her perspectives on who she wants to be. She lives in a patriarchal society where male authority takes precedence. It is a world taught by, and addressed to men, thus emphasizing the disparity between genders. For Isabella, to define who she wants to be and decide what is her idea of the good life depends on her dialogical relations to others and implies negotiations "through a dialogue, partly overt, partly internal, with those who matter to her $^{51 \%}$. Men then were considered honourable through extrinsic demonstrations of honour: for winning battles as well as protecting their nation, their people, and their civilized and religious $^{52}$ values.

Where Isabella is concerned, "intangible form of reputation" is likely to be the ultimate goal. She lives in a society where women were thought not capable of achieving virtuous acts and, hence, their honour and respectability was intrinsically oriented. This

\footnotetext{
${ }^{51}$ Fahmi, "Quoting the Enemy: Character, Self-Interpretation, and the Question of Perspective." p. 132.

52 It is important to keep in mind that Christianity and religion crucially influenced society during Renaissance. In England most specifically, monarchy was authority figure for both politics and religion.
} 
honour was linked implicitly to something not attainable without consent: their virginity. Accordingly, her comprehension of honour is that, in order to remain in the good favours of those surrounding her and maintain a flawless reputation, she must stay virtuous. Now, the issue lies in the definition of what is to be considered virtuous.

\author{
Angelo: Say you so? \\ Then I shall pose you quickly. \\ Which had you rather, that the most just law \\ Now took your brother's life, or to redeem him \\ Give up your Body to such sweet uncleanness \\ As she that he hath stained? \\ Isabella; Sir, believe this, \\ I had rather give my body than my soul.
}

(II.vi: 50-56)

For Isabella, chastity exceeds bodily status; it is purity profoundly engrained within the soul. In Measure for Measure, arguments on virginity as such are non-existent and this excerpt reveals that her conception of honour transcends mere physical purity. For Isabella, remaining virtuous surpasses basic protection of virginity. Her conception of virtue through virginity is in "dialogue" with the message conveyed in her times. Interestingly enough, everywhere in the text, the discussion focuses on chastity and, from her reaction when it is mentioned, Isabella surely sees difference between virginity and chastity. Chastity is not just a physical concept; its ramifications are profoundly embedded within what she is as an individual - in her identity.

Angelo:... Of the all-binding law, and that there were No earthly mean to save him, but that either You must lay down the treasures of your body To this supposed, or else to let him suffer,

What would you do?

Isabella: As much for my poor brother as myself. 
That is, were I under the terms of death,

Th'impression of keen whips I'd wear as rubies, And strip myself to death as to a bed

That longing have been sick for, ere I'd yield

My body up to shame.

Angelo: then must your brother die.

Isabella: And 'twere the cheaper way.

Better it were a brother died at once

Than that a sister, by redeeming him,

Should die for ever.

(II.iv: 98-107)

As far as Isabella is concerned, there is no option when her chastity is at stake. The perception of sexuality by the Shakespearian society surely had a reinforcing effect on Isabella's views on chastity. A negative perception of sexuality is clearly made available to us throughout Measure for Measure. The Duke's mention of Pompey's "filthy vice" and Juliet's "most offenceful act" definitely set the tone, as does Isabella's own perspective, “... I should do what I abhor to name, or else thou diest tomorrow" (3.1:100), strongly emphasises it. Sexuality was then regulated by religious doctrine and turned into a supposed latent act associated with sin, fall and death. It became acceptable in one situation and for one main reason: in monogamous unions and strictly for procreation ${ }^{53}$.

In the Renaissance, sexuality was viewed as a transgression and an offensive violation liable to consequences ranging from public humiliation to harsh corporal punishment. Moreover, feminine sexuality, regarded as the instigator of the "original sin" and the bearer of eternal misery and death into the world, was perceived as odious, vile, and distrustful. It rhymed with contamination and disgrace. This necessarily animates two of the

${ }^{53}$ Foucault, Histoire De La Sexualité Ii: L'usage Des Plaisirs. p. 22. 
"three axes of ethical thinking, ${ }^{54 "}$ which, for Isabella, underpins her concepts of the good life and dignity or self-respect. Self-respect is thus a part of both her identity and her integrity. Isabella defines her notion of good life in accordance with the concepts and ideas diffused in her society as she sets the typical features to command respect of others.

Because it was linked to honour, sexual conduct became a matter of public concern. Women were presumed to lack the self-control men could boast about ${ }^{55}$. On these accounts, it became necessary to have a significant male figure to ensure proper conduct. Husbands became their wives' managers. Christian morals promoted a clear and obvious difference between men and women where sexual behaviour is concerned. Women were constrained to austere, draconian restrictions not imposed on men. They were regarded more as objects, or at the most, partners that had to be trained, educated, and supervised. Marital unions were a way to regulate a woman's assumed disposition to stray in sinfulness. Thus, women were believed to acquire intelligence through marriage ${ }^{56}$. Since "discovering one's own identity doesn't mean working it out in isolation, but that one negotiates it through dialogue, partly overt, partly internal, with others... and thus that, one's own identity crucially depends on one's dialogical relations with others ${ }^{57}$, , it is plain to see that Isabella is reacting to all the ideas circulating around her, and consequently, her conception of the

\footnotetext{
${ }^{54}$ Taylor, Sources of the Self: The Making of the Modern Identity. p. 15.

Taylor singles out three axes of ethical thinking: our sense of respect for and obligations to others, our understandings of what makes a full life, and the range of notions concerned with dignity.

${ }^{55}$ FOUCAULT, Michel, Histoire de la sexualité II: L'usage des plaisirs, France, Éditions Gallimard, 1984, p. 33.

Foucault mentions that, in Greek antiquity, self-control was a very crucial aspect of honour. The Greeks thought that one who could keep emotions (stoicism), as impulses and desires (emotional and sexual) showed willpower and consequently gained the honour, dignity and trust needed to access to governing positions

${ }_{56}^{56}$ Foucault, Histoire De La Sexualité Ii: L'usage Des Plaisirs. p. 33.

${ }^{57}$ Taylor, Human Agency and Language: Philosophical Papers. p. 45-76.
} 
self is fashioned in concordance with the message conveyed about sex, about out-ofmarriage birth, and in dispute with the conception of woman as object.

Through the interlocution provided by these elements, Isabella gets a sense of who she is and articulates her identity by being oriented towards what she considers her ultimate good. She situates her "self" in dispute with her society and through the values conveyed at that particular time. Even if Isabella is a reflection of her epoch, her definition of who she strives to be is in concordance with what determines her background of intelligibility. In the world of depravity and perversion she lives in, chastity is her "worth of life", and thus the kind of life she considers worth living. She is a "self-interpreting" subject in the sense that her life priorities and motivations are modeled and acquired through the rich language of expressions provided by culture, principles, ideology, and philosophy of her own epoch. From the latter, she is able to situate her SELF within a perspective oriented towards her ideal, and hence her happiness and self-affirmation.

Similar to how Isabella has a definite idea of her identity and who she wants to be, her selection of the components susceptible to lead her to happiness derive from ethical evaluations. Her choices stem from the certitude that not only is her higher good the utter most and valuable among all, but it is also the ultimate factor that will bring her absolute contentment. Isabella's ethical choices, and accordingly her force of character, are strengthened by the ongoing dialogues around her. Even when confronted by situations where her moral path is called into question, Isabella does not deviate from what is ingrained within her: 
Angelo: Say you so? Then I shall pose you quickly.

Which had you rather, that the most just law

Now took your brother's life, or to redeem him

Give up your body to such sweet uncleanness

As she that he hath stained?

(II.iv: 50-54)

She is unwavering when her chastity is threatened and will not give it up no matter the stakes. Isabella's refusal to yield to Angelo's dishonest propositions, no matter what the outcome might be, is quite revealing of her strength of character as of who she is. Her selfinterpretation is made available to us not from what others say, but from her unpropitious response to Angelo and to her own brother. She repels Angelo's advances without apprehension as she callously advises her brother to prepare for death:" Be ready, Claudio, for your death tomorrow" (III.I: 106), and concedes neither to Angelo's intimidation nor to Claudio's begging request.

The social situation pertaining to women further complicates Isabella's animus and influences the way she perceives herself. She lives in a time where sex and pregnancy go hand in hand. In this fashion, the only option for a woman to maintain an unfailing reputation was through marriage ${ }^{58}$. Coition outside marriage and its ends, bastardry, incest and diseases, are to be avoided to access honour. Yet, in Vienna's society, premarital sexual acts are forbidden and sanctioned. In the play, sexual temptation is defined as " $a$ thirsty evil" from which one catches death, which demonstrates Renaissance ideas of sex. For a woman, the loss of virginity could bring about a tarnished reputation, which could bring

\footnotetext{
${ }^{58}$ Kamps, Measure for Measure: Texts and Contexts. p. 186.

The authors argue that, in Shakespearean times, matrimony was the social act of excellence, the one on which all others relied. It is through this institution that relational affiliations between individuals and families came to exist, that sexual consummation and thus, procreation and continuation of a nation was insured and sanctioned by both religion and government.
} 
scandal to her relations. Furthermore, it could have long lasting and disastrous consequences not only on her life but on everyone close to her as well. In this sense for Isabella, loss of chastity was condemnable and what could result from it was the most unbearable psychological disgrace. Indeed, the consequences of loss of chastity are Isabella's driving force for preservation of her own.

Women are the reproductive space, and the continuance of the human race rests upon them. Hence, women are the bearers of legitimate heirs for the family estates and inheritance. Of all the consequences, illegitimate engenderment aggravates Isabella the most because the child will be forever branded in sin and live a life of eternal misery. In this play, bastardry is viewed as "procreation made in the wrong manner" 59 ". This was a determinant factor for the preservation of a woman's integrity, a preservation that became, in a sense, a means of sustaining genealogy insuring inheritances through official descendants' lineage ${ }^{60}$. Isabella knows all too well the outcomes of premarital intercourse: "I had rather my brother die by the law that my son be unlawfully born." (III.i:187-189)

An interesting and most influencial argument in Isabella's self-fashioning is the perception of women in the androcentric society she lives in. It is needless to say that all the social concepts, like honour and how it should be perceived for both men and women, are,

${ }^{59}$ (II.IV:46-49) Angelo: "Ha! Fie, these filthy vices! It were as good to pardon him that hath from nature stol'n a man already made, as to remit their saucy sweetness that do coin heaven's image in stamps that are forbid. 'Tis' all as easy....Falsely to take away a life true made, as to put mettle in restrained means to make a false one" Angelo here argues that unmarried women, with their forged angel faces trick men into making a life using forbidden methods.

${ }^{60}$ Kamps, Measure for Measure: Texts and Contexts. p. 181-190.

Marriage was the official stream of inheritance; it is through this social act that properties, estates, wealth, thrones, and titles are transmitted, and through which legitimate heirs originate. Bastardry would complicate the transfer of inheritance, of properties, and the likes. Marriage was a social institution from which one could not only aspire to respect from peers and honour, but also inherit these from illustrious predecessors. Ultimately, the laws forbidding fornication were instituted to prevent social chaos brought about by its results. 
in Shakespearian times, viewed and thus determined from masculine perspectives. Considered as heiresses of Eve's original sin, Renaissance women were thought of not only as the weaker sex, but also as Satan's medium of corruption to men's lives. Aristotle said that women were more imperfect than men in all aspects, leading them to greater susceptibility to emotions and other irrational behaviours, ${ }^{61}$ and making them more inclined to give in to their impulses. A woman was thought to have one "unique" honour and, to validate the existence of this virtue, she had to remain compliant to a befitting male figure of authority like a father, a brother, or any responsible, valid man, unless she was part of a congregation and within nunnery walls.

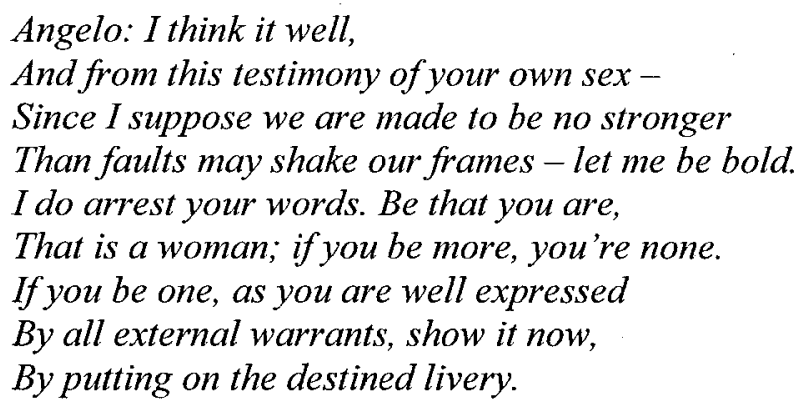

(II.iv:131-139)

This conception of women impacts Isabella's perception of the good and her interpretation of the self. She is surrounded by the ideology of her time, which says women are merely "second persons: beings who become and exist as persons only in relationships with persons ${ }^{62 \%}$. Isabella's reaction to these ideas reveals her strength of character; notwithstanding the fact that she stands as part of the inferior portion of society, she nonetheless believes in her worth. Her responses, which are in dispute with her society's

${ }^{61}$ KAMPS, Ivo, RABER, Karen, Measure for Measure; Texts and Contexts, Boston, New York: Bedford/St. Martin's, p. 186, 2004.

${ }^{62}$ Anne Baier in, Robin S. Dillon, ed., Dignity, Character, and Self-Respect (London (UK): Routledge, 1995). p. 296. 
conceptions of women, are focused towards long term consequences and not on immediate results. Her responses are governed by reason and not desire. The grounds for her preference are shaped by the variants sculpting Isabella's moral space, which permit her to establish what is good or bad, and to judge what is best for her. In that sense, Isabella becomes a strong evaluator; an agent in the way she, inflexibly and unyieldingly, develops her sense of dignity in an environment striving to ruin and deform her self-esteem and selfworth. Her actions and decisions are directly linked to her orientation. Her self-perception is founded on the precepts of the higher good she beholds as ultimate and above all others, and thus, defines the means and actions to access the good life. As a matter of course, Isabella sees her chastity as a way to honour, dignity, and self-respect that provides a sort of liberation from the constraining requisites imposed on her as a woman living in Renaissance society.

This also implies that the grounds of her actions are not necessarily indebted to her past, but can very well be found in her future, that is to say, in the goal that directs her action or inaction. For Isabella, self-perception is not a mere question of what is right or what is wrong; it is a question of being loyal to what defines her identity. It becomes an expedient susceptible to provide her high stances in the social order, to lead her to utter contentment, to what she considers her higher good, what shapes her decisions, and consequently, her actions.

Elizabethan and Jacobean contemporaries are motivated by the benefits in the subsistence of honour as they despise the lack of it, namely shame. 
Isabella: Yes, brother, you may live.

There is a devilish merci in the judge,

If you'll implore it, that will free your life

But fetter you till death.

Claudio: Perpetual durance?

Isabella: Ay, just - perpetual durance, a restraint,

Though all the world's vastidity you had,

To a determined scope.

Claudio: But in what nature?

Isabella: In such a one as, you consenting to't,

Would bark your honor from that trunk you bear,

And leave you naked.

(III.i: 63-72)

For Isabella, as for her contemporaries, shame is perpetual damnation. On one aspect, perception of shame towards other individuals is a difficult experience in itself considering the fact that, if it exists, it is because there is fondness felt towards these individuals. However, what Shakespearian contemporaries mostly fear is shame brought upon the self. As a member of a religious community, Isabella's choice of a higher good is influenced by Adam and Eve and the notion of original sin. In Isabella's case, shame is more profound and spiritual, and confronts her soul and God.

Thus, preservation of chastity is the answer to avoid this shame which would be an eternal burden to bear not only in the eye of humanity, but in the face of God, as it was for Adam and Eve. Kierkegaard's claim that "in any individual human life, puberty and loss of virginity, which bring carnal knowledge and new fantasies and temptations that make the spirit foreign to itself and analogous to the original loss of innocence in the Garden of $E d e n^{63, ", c o u l d}$ very well explain Isabella's motives. On these premises one is then more apt to comprehend the grounds upon which Isabella defines her chastity. The shame emanating

${ }^{63}$ E Fernie, Shame in Shakespeare (London: routledge, 2002). p. 33. 
from a loss of chastity does not only stem from human criteria. In a more crucial aspect, shame in this case rises from God as from her own conscience and soul. Shame then becomes an impediment to her spiritual access to the Almighty.

For this reason, Isabella's main concern is to convince her brother that her chastity has more importance than his life. Her assumptions are undeniable. From her perspective, yielding to Angelo's advances would imply that her brother would have to drag the eternal burden of dishonour not only upon himself but on his ancestors as well as on his descendants. The situation is unbearable and unacceptable to Isabella. Honour, which emboldens her character, is profoundly engraved within her identity and explicitly linked to her chastity. The loss of her chastity would mean meandering in eternal shame, which to Isabella, is totally unconceivable. For her, there is no other way of achieving virtue than raising chastity above all other virtues. The complexity of her perspectives of honor shows the profound dimension of the following words:

Then, Isabel, live chaste, and, brother, die: More than our brother is our chastity.

(III.i:183-184)

In Measure for Measure, women could keep worth and honour exclusively through one the following statuses: a maid, a wife, or a widow. There are no other honourable alternatives to consider aside from these as made evident in Lucio's observations.

"Duke: What, are you married?

Mariana: No, my lord.

Duke: Are you a maid?

Mariana: Neither, my lord. 
Duke: Why, you are nothing, then, neither maid, nor wife?

Lucio: My lord, she may be a punk, for many of them are neither maid, widow, nor wife."

(V.i: 172-181)

All three provide an indication of the state of a woman's virtue. Specifically, that is whether or not she is a virgin, nuptially chaste or abstinent. Whether it be before, during or after it, all three terms are, in some fashion, related to marriage and sexuality. They are the reflection of the defining norms of femininity in Vienna, and provide, for most, the threshold of identity for women, as for men. In this sense, the men of Vienna have a definite concept of what an authentic, normal woman should be:

be that you are, That is, a woman: if you be more, you're none; If you be one (as you are well express'd By all external warrants), show it now, By putting on the destin'd livery

(II.iv: 134-138)

Angelo demands and expects, as all the men of the play do, that Isabella comply with the normal patterns of her society. However, they are patterns that she rejects with vehemence. The gender standards of Vienna add to Isabella's difficulty to assert her true self. She lives in a world where what a woman is expected to be is set by a society governed by men. From the Viennese men's point of views, Isabella's identity relies, first and foremost, on her gender and the inferences made about gender by the patriarchal standards of Vienna, which affirm female identity of conception. Angelo's declaration is explicit: "Why, you are nothing then" (V.i: 177). For a woman, expectations are similar for 
all; if she does not agree to sex, she has no identity. In this culturally constructed view of feminine identity, being a nun is no different than a wife, or widow or punk for that matter. If Isabella does not conform to the available image of femininity, and does not assure the function according to her masculine entourage, she is not considered a real woman. Isabella's disagreement towards the situation only adds to her strength of character. Her inflexible inward convictions bestow upon Isabella the fierceness and tenacity to maintain her position no matter the issue.

Under these premises, one with no aspirations for marital and family life, or a woman having no desire for a life governed by a meaningful male figure like a father or husband, had no other suitable option than to join a religious order, thus giving Isabella, and others as well, reasonable motives to value her chastity. For her, rather than being a form of subservience to the patriarchal social structure of her epoch, chastity is a form of resistance against the immorality and sexual laxity prevailing in her society and time.

Isabella's appraisals, and thus her actions, are regulated by the dominant and fundamental elements prevailing in her era. These elements contribute to the construction of her "background picture," the moral blueprint Isabella exerts to account for the standards of evaluation defining moral issues, and hence the choices in her vision leading her to a worthy life. This background picture must be taken under consideration to make sense of Isabella's identity and ethical selections which rely on much more than a mere caprice. Defining an individual's identity requires more than merely making a judgemental discernment towards someone to get a sense of who one is. To others, apparent noticeable 
aspects of a person are an advantageous asset, to be sure, but evidently not the only component upon which one can set a definite conception of another's identity.

Interiority and depth are features that need to be taken into consideration and the impact they have on one's reasons to take action or not. Unfortunately, this information is indubitably unavailable to us. At most, others can only have partial access to such concealed, intimate and confidential facets of an individual. So on Isabella's account, whether her perception is mistaken or not, that is the way she wants to be sanctioned by others, it is nonetheless what she aspires to be. Therefore, the only way to access her genuine interiority is in investigating Isabella's relationship with others and the way she situates herself within her society and times.

For Shakespearean characters, there are always one or many elements that represents the quintessence of the good life, and the identity crisis that some characters undergo stems from the loss of one or many of these elements, leading to disorientation ${ }^{64}$. It follows that, for Isabella, the good life is available only within unstained and shameless honour, which is obtainable exclusively through the preservation of her chastity. Ultimately, from her perspective, chastity is the worthiest of goods. This is what gives her worth. She is opposed to what others require of her and will, under no circumstance, yield to their claims. The life in chastity is the moral space that provides a comprehensible language of articulacy. This allows her to communicate with others. She is faithful to her choice and convincingly makes her point to whoever challenges her. Isabella is a true self-interpreting subject in the manner in which she makes sense of herself and constructs her identity. Chastity and a

${ }^{64}$ Fahmi, Shakespeare's Poetic Wisdom: Identity, Orientation, and Historical Providence in the Henriad. p. 19. 
strong evaluation on Isabella's part, is inseparable from her identity. It is the kind of life she considers worth living, it defines her orientation in respect to her conception of the good, and it is her sense of worth of life.

Duke:...Dear Isabel,

I have a motion much imports your good,

Where to if you'll a willing ear incline,

What's mine is yours, and what is yours is mine.

So, bring us to our palace, where we'll show

What's yet behind, that's meet you all should know.

(V.i:532-537)

Many claim that Isabella undergoes a change for the better by the end of the play ${ }^{65}$.

For instance, Anne Barton argues that "as Angelo, she has arrived at a new and juster knowledge of herself ${ }^{66}$ " by the end of the drama. My argument is that, from the very beginning of the play, she is THE character with the most profound awareness of herself and it is exactly this issue that provides guidance in the choices and decisions she has to take concerning her happiness.

For Isabella, being a nun is more of an alibi than a vocation. The convent is a comfort zone; a place where Isabella finds not only security and the reassuring and embracing sense of community; a place where men have no access and hence no control of the women living within its boundaries. This status is basically a means to ensure her purpose. It is a status where she can remain in control of her own fate away from the chaotic, decadent society she does not approve of. Her turning to religion is an expedient

\footnotetext{
${ }^{65}$ Alice Shalvi "The Relationship of Renaissance Concepts of Honour to Shakespeare's Problem Plays," Univertität Salzburg, 1972. p. 249.

${ }^{66}$ Bloom, Modern Critical Interpretation: William Shakespeare's Measure for Measure. p. 4.
} 
towards purity and moral uprightness in spite of the fact that fornication and depravation are common behaviours in her times. Thus the intricate concepts of virtue and honour crucially contribute to the shaping of her character. They are part of the infrastructure upon which she orients herself to determine the principles dictating her conduct and actions. As the strong evaluator that she is, Isabella's preferences are defined according to a moral evaluation and not in accordance with the immediate wants to fulfill. This endows her with the ability to legitimize, compared to others, a sense of her life. Her actions are driven by both the way she defines herself and where she is situated within her era and are, furthermore, in concordance with the important elements establishing her moral limits.

To be deprived of her preferred good, namely her chastity, would imply the destruction of the reference points upon which her identity is founded and would thus, incur a loss of orientation ${ }^{67}$ or an identity crisis, which could very well be a possibility in Isabella's case if no changes had occurred around her. But since evil has now been purged from Vienna, Isabella sees no need for chastity and life in a convent. She may consider returning to life in society.

\footnotetext{
${ }^{67}$ Taylor, Sources of the Self: The Making of the Modern Identity. p. 29.
} 


\section{CHAPTER II}

"They, who stand forth the foremost in danger for the community, have the respect of mankind."

Samuel Johnson

\section{"To-morrow I'll to Wars, She to her Single Sorrow" ${ }^{68 "}$ Self- Interpretation and Honor in All's Well that Ends Well}

There is no other work of Shakespeare's which in conception and in temper seems quite so corrupt as this... There are other works of Shakespeare which are more painful; there are none less pleasing, none on which one cares less to dwell... Everyone who reads this play is at first shocked and perplexed by the revolting idea which underlies the plot... it leaves so unpleasant a flavour with some people that it is not tasted again.

This comment, by Barrett Wendell ${ }^{69}$, presents the general annoying impression shared by most readers of All's Well That Ends Well". Categorized as "the feeblest of the lot, dramaturgically and psychologically ${ }^{71}$, , this play has confused and repulsed both critics and readers rather than delighted and enchanted them. Contrastive generational perspectives, diverging opinions pertaining to social status, and disruption of gender norms ${ }^{72}$ make it

\footnotetext{
${ }^{68}$ Shakespeare, "All's Well That Ends Well."

${ }^{69}$ Barrett Wendell cited in Paul Gleed, All's Well That Ends Well, Bloom's Shakespeare through the Ages, ed. Harold Bloom (New York: Bloom's Literary Criticism, 2010). p. 77.

${ }^{70}$ David Bevington, The Complete Works of Shakespeare, 5th ed. (Pearson Longman, 2004). P. 374-413.

${ }^{71}$ Gleed, All's Well That Ends Well. P.74.

${ }^{72}$ The gender role reversal is a good example of this. Up until the beginning of the $20^{\text {th }}$ century, women were expected to show patience pertaining to love relationships; they were left to anticipate married life and could in no way entice it. It was a time where women had no say in the issue.
} 
difficult to contemplate. Referred to as "the unfortunate comedy" ${ }^{73}$, this play stands among the least praised and performed of all of Shakespeare's dramas. The play is so particular that it has been thought to be an experimental exercise not meant to be staged $^{74}$.

The reasons for the lack of interest in All's Well are numerous. Many have agreed that "the repellence and weakness of theme" have left many with unanswered and unanswerable questions. Recent years have brought new perspectives on it with the emergence of new critical approaches, like psychoanalysis, feminist criticism, and the question of human rights, to name a few. And, with these new approaches, All's Well That Ends Well becomes adaptable to our era. At last this play's foremost dilemma has been found: its modernity. With the arrival of new literary concepts, critics become more forgiving and complimentary toward the play. As Terry Eagleton declares, "though in many ways we appear to have left Shakespeare's age behind, there are other ways in which we have yet to catch up with him ${ }^{76}$." In this sense, All's Well That Ends Well confirms, in a most perfect way, that "Shakespeare was not of an age, but for all time"

Other misleading irritants of this play are the irregularities and the deficiencies, in roles and in attitude, of its characters. One can easily think of them as downgraded versions, as pale duplicates of, certain others in past plays: Helena who, as Rosalind or Viola, is domineering and scheming in love but whose results are unconvincing; Paroles,

\footnotetext{
${ }^{73}$ J. G. Price, The Unfortunate Comedy: A Study of All's Well That Ends Well and Its Critics (Toronto: University of Toronto Press, 1968). p. 2.

${ }^{74}$ Gleed, All's Well That Ends Well. p. 23

${ }^{75}$ William Shakespeare, Oxford : Blackwell, 1987, p.5, cited in G. Waller, All's Well That Ends Well: New Critical Essays (New York: Routledge, 2007). p. 2.

${ }^{76}$ William Shakespeare, Oxford: Blackwell, 1987, p.5, cited in Waller, All's Well That Ends Well: New Critical Essays. p. 2.

${ }^{77}$ Ben Johnson cited in Gleed, All's Well That Ends Well. p. 72.
} 
who could be very well compared to Falstaff were he not so conniving and despicable. Bertram turns out to be a counterfeit version of Hotspur, a knight of another time. The ensuing summary of the play provides a clear idea of the two protagonists and what leads critics and audiences to judge them so harshly.

Bertram, a callow and immature aristocrat, is forced into marriage against his will to Helena, a beautiful and virtuous maiden. Since he is without love or desire for her, he decides to flee both his new responsibilities as a husband and his home-country, France. He escapes to Italy to battle in the wars between Sienna and Florence in the hope that his new situation will justify a divorce. While away, he attempts to seduce Diana, a Florentine young woman, and sends a missive to Helena containing the prerequisites that he requires of her before he validates her as his spouse. However, these are basically unfeasible since he requests that she be with child by him and wearing his family heirloom, an ancestral ring. The outcome would then be an instantaneous and mostly honourable divorce. But clever, ingenious Helena has other plans in mind. Nothing will stop her from winning Bertram's love. Her implausible, intriguing scheme of duplicity, the notable bed-trick with Diana's cooperation, will climax into a final resolution drastically drenched with dissonance and insincerity. Even the title lacks coherence. Is ALL really well and does ALL really end well?

Firstly, the protagonists are foils to one another, each one emphasizing the other's moral qualities and flaws. The goodness of Helena, considered by many as "the finest specimen of moral fortitude, with feminine true delicacy of sentiment ${ }^{78,}$, and surely among

\footnotetext{
${ }^{78}$ Gleed, All's Well That Ends Well. p. 42
} 
Shakespeare's loveliest heroines, definitely eases judgment on Bertram in a most pernicious way. "Bertram is, really, a dirty dog - a thoroughly dirty dog: he is an aristocrat, not of the "first water," but of the last - the lowest water -sewer water. He is weak on judgment;... imperious and head strong, treacherous, a liar and coward... Not a war coward, like Paroles, but a moral coward ${ }^{79}$. . Positive judgments are bestowed upon virtue than the opposite. However, my question is: what impelling forces push Bertram to refuse his king's wishes, to reject such a young beautiful bride and the comfort of being a married man? The answer lies in making sense of Bertram's actions not through how others perceive him, but through the way he perceives himself.

The following passage may very well be interpreted as a rendition of Bertram's past, present and future: He is noble born, very young, and quite a lot is expected of him.

Countess: Be thou blessed, Bertram, and succeed thy father In manners, as in shape. Thy blood and virtue Contend for empire in thee, and thy goodness Share with thy birthright. Love all, trust a few, Do wrong to none, Be able for thine enemy Rather in power than use, and keep thy friend Under thy own life's key. Be checked for silence, But never taxed for speech. What heaven more will, That thee may furnish, and my prayers pluck down, Fall on thy head! Tis an unseasoned courtier. Good my lord, Advise him.

His mother, the Countess of Roussillion, is the widow of a highly regarded aristocrat. The first duty assigned to Bertram is to be a good son, one pertaining to "Honor

\footnotetext{
${ }^{79}$ Ibid, p.42.
} 
due to parents: the reason why because we have our beginning from them... ${ }^{80}$ ". Hence, as the well-raised son that he is, Bertram most certainly vows utter respect to his mother, the Countess, as to his recently deceased father. As the good son that he thought to be, Bertram is, to be sure, sensible to such words coming from his dear loving mother. To fully grasp the impact of such words on Bertram, it is important to understand the perception of virtue and honour in Renaissance society. "The basic values of society were given, predetermined and so were a man's place in the society and the privileges and duties that followed from his status ${ }^{81,}$. A man's social position was predetermined by his right of birth; this position assigned a social debt upon him towards others in the community and it established that others, from their own social status, had a debt towards him. From the very beginning, one not only knew where one stood within the social structure, but also what was expected from others and what was owed to others from one because of their respective social positions. Thus, Bertram knows not only where he stands in his society, but from the message conveyed around him, he also knows what is expected of him and what he should expect from others. The countess, Bertram's loving mother, contemplates him as the legitimate "in manner as in shape" (1.i:62) to a loved and highly cherished, deceased father. From the Countess' words, Bertram is expected to live up to his father's status and reputation. Like his father he is ward to the King, a position that, in the Shakespearian aristocracy, is a great privilege. In Renaissance France, as in England and Italy, nobles are part of the military troops. They are deeply attached to the land they have been granted for worthy services by kings and will go to all lengths to defend it. Accordingly, intricate bonds between the vassal

\footnotetext{
${ }^{80}$ R. Hooker., "Of the Laws of Ecclesiastical Polity", When Honor's at Stake, Norman Council, New York: Harper \& Row Publishers, 1973, p.16.

Hooker argues "that all public roles which a man might play" are assigned with specialized kinds of virtuous actions which, in turn, involve a return of honor upon realization of these actions.

${ }^{81}$ Alasdair MacIntyre, After Virtue (Notre Dame: University of Notre-Dame Press, 1981). p. 115.
} 
and the royal authorities are created because of the complexity of property rights. To guarantee the country's political tranquility, it is crucial to ensure loyalty as a valuable commodity. Oaths were to be taken as proof of devotion and loyalty to the monarch ${ }^{82}$.

The positions of courtier and soldier held distinct functions. The first focused on Shakespeare and Castiglione's ideal of the Renaissance courtier; that is, an individual who fashions him or herself in the prime courtly values of loyalty, magnanimity, and honour. Furthermore, the courtier is one who pursues self-knowledge focussed on social consciousness rather than on personal designs; one in which "virtues of the humanistic scholar... are united with those of the medieval knight... whose main purpose is to glorify the monarch ${ }^{83 "}$ at any cost. Courtesy books mention that birthright made one pre-disposed to virtue by rendering the appropriate environment to make it possible ${ }^{84}$. Conversely, Bertram's heritage supplies exactly that. Since birth, Bertram has dwelled in virtue of the accomplished, erudite scholar; he has been taught the classics and is honour-bounded by this heritage. Bertram has acceded to his social position, ward to the King, and he is willing and ready to assume his new official functions, and willingly embraces the responsibilities linked to them:

Bertram:"And I in going, madam, weep o'er my father's Death anew; but I must attend his majesty's command, To whom I now in ward, evermore in subjection."

\footnotetext{
${ }^{82}$ J. Russell Major, From Renaissance Monarchy to Absolute Monarchy: French Kings, Nobles, \& Estates (Baltimore: The Johns Hopkins University Press, 1994). p. 93.

${ }_{83}$ Council, When Honor's at the Stake: Ideas of Honor in Shakespeare's Plays. p. 32.

${ }^{84}$ P.N. Siegel, "Shakespeare and the Neo-Chivalric Cult of Honor," The Centenial Review of Arts and Science 8.1 (1964). p. 42.
} 
The young man is conscious of the implication of his new role. As a king's ward, he is ready to play this role where specific duties as a courtier are appointed and expected of the candidate.

The second function of a ward is that of a soldier, a knight ready to virtuously give his life for his country, for his King, for his people, and through their acknowledgement for his good actions, gains the ultimate gift of honour. The private soldier status demands of Bertram that he bestow "honour due unto kings and governors: the reason why, and because God hath set them 'for the punishment of evil doers, and for the praise of them that do well ${ }^{85}$." As part of aristocracy and everything it implies, Bertram holds royal authority in the highest esteem and reverence. In "Man's Chief Good" Mustapha Fahmi claims that Shakespeare's characters become human agents because they are engaged in a continuous dialogue or dispute with those who matter to them ${ }^{86}$. The following excerpt shows a genuine example of a significant dialogue between Bertram and those he considers his most meaningful interlocutors to whom he owes all esteem, the king and the Countess. Consequently, he vows utter respect to the King and certainly complies with the royal power conferring honour and reward onto those who are revealed worthy of it, as punishing those in wrongdoings. Additionally, the Monarch equally holds Bertram in high regard for the young ward happens to be his best friend's son. He considers Bertram as his own. The King eloquently shows his profound appreciation, affection, and attachment to Bertram's father:

\footnotetext{
${ }^{85}$ R.Hooker, "Of the Laws of Ecclesiastical Polity" Council, When Honor's at the Stake: Ideas of Honor in Shakespeare's Plays. p. 16.

${ }^{86}$ Fahmi, "Man's Chief Good: The Shakespearean Character as Evaluator."
} 
King: I would I have that corporal soundness now As when thy father and myself in friendship First tried our soldiership. He did look far Into the service of the time, and was Discipled of the bravest.... It much repairs me To talk of your good father; in his youth He had the wit which I can well observe Today in our young lords;.......

So like a courtier, contempt nor bitterness Were in his pride, or sharpness. If they were His equal had awaked them, and his honor, Clock to itself, know the true minute when Exception bid him speak, and at his time His tongue obeyed his hand. Who were below him He used as creatures of another place, And bowed his eminent top to their low ranks, Making them proud of his humility, In their poor praise he humbled. Such a man Might be a copy to these younger times, Which, followed well, would demonstrate them now But goers backward.

Bertram: His good remembrance, sir, Lies richer in your thoughts than on his tomb. So in approof lives not his epitaph As in your royal speech.

Bertram listens with uttermost attentiveness to the King reminisce about the valiance, the acute military skills, and the glory of his precious friend, the late Count of Rossillion. Tales such as the King's are the channel through which virtue is transmitted to the forthcoming generations of heroic societies, where soldiers and warriors will be looked upon as the archetype of virtue. Such tales are a channel through which "one way we both discover, and also create, who we are, because it is a representation of the world and life... it is an imitation not of persons but of actions and life. In a good story one can recognize oneself, not as one is but as one wishes to be. It provides a representation of a higher self, 
noble, wise, courageous and good. It provides people with a version of the accomplished self one strives to be ${ }^{87}$. In all evidence, the importance that the King's tale has on Bertram, an enthusiastic youth, most certainly has its effect on what he wants to be. The young lord is mesmerized by his father's fame and radiant reputation. This determines his preferred purpose in life.

His father was a fearless, courageous, virtuous and diplomatic soldier. These praises, more than ever, emphasize Bertram's wish and duty to live up to his father's "honorèd name" (I.iii: 152), earn a reputation of his own, and show his worth to the King. During the Renaissance, "the word aretê, later to be translated as 'virtue', is in the Homeric poems used for excellence of any kind; ... a son excels in his father in every kind of aretêas athlete, as soldier and in mind ${ }^{88}$." Alasdair MacIntyre argues that, in the Renaissance, this concept of virtue was considered the centre element in the understanding of human greatness and worth. This concept certainly prevails in the establishment of Bertram's "background of intelligibility, the framework crucial to the articulation of identity" ${ }^{89}$ Thus, it is exclusively in dialogue with the royal authority's discourse that Bertram sets the limits of what Charles Taylor designates as "moral space", a point of view from which one can decide what is good or bad, what is to be accepted and what is to be opposed ${ }^{90}$. He chooses to embody what his cherished and esteemed father was "in manner and in shape" (I.i: 62), and defines it as what he wants to be a soldier.

\footnotetext{
${ }^{87}$ Brendan Myers, The Other Side of Virtue: Where Our Virtues Came from, What They Really Mean, and Where They Might Be Taking Us (O Books, 2008). p. 32.

${ }^{88}$ MacIntyre, After Virtue. p. 115.

${ }^{89}$ Taylor, Sources of the Self: The Making of the Modern Identity. p. 29.

${ }^{90}$ Ibid. p. 29.
} 
The life of a soldier is what Bertram values ${ }^{91}$ as the ultimate good susceptible to give sense to his existence. It is the ethical option that will make him worthy of his social status, that will justify his inheritance. It is what will provide acknowledgement from the King, the Countess, and his peers, namely those who matter to him, and this sets this choice apart from all others. It then becomes "the good deemed higher than others" 92 " and thus the ultimate way to happiness. This ethical and conscientious preference residing in the innate self becomes the purpose to the valuable and rewarding existence. Being a soldier is how he wants to exist and he will do everything in his power to epitomize his ideal. It becomes his ultimate way to dwell in happiness, his highest valued aspiration. Bertram's notion of the good is influenced, to be sure, by the message conveyed through the culture of his time, and thus by what he conceives of the perfect soldier:

... A man of the world, bearer of an attitude of those who have experienced living in various countries and among various cultures. One at home everywhere and whose quarters and rations are all his care; where he fares best, that place is home. Always braced for action and hard service; and he is not more careless and light-hearted when he joins his comrades in a "lark". He will head a forlorn hope, entrap and badger a poltroon with the like sedateness and determinations of purpose.... all are duties to honor, and he fulfils to the utmost of his faculties ${ }^{93}$.

Bertram wants to live according to the archetype of soldiering as it is displayed in many Shakespearean plays comparable, for instance, to Hotspur ${ }^{94}$, and will do everything

\footnotetext{
91 Taylor, Human Agency and Language: Philosophical Papers. p. 15-44.

${ }^{92}$ Fahmi, The Purpose of Playing: Self-Interpretation and Ethics in Shakespeare. p. 25.

${ }^{93}$ Charles Cowden Clarke in Gleed, All's Well That Ends Well. p. 48.

${ }^{94}$ Shakespeare, "The First Part of King Henry the Fourth."
} 
to achieve his ultimate standard of excellence. The young man judges, with all worthy soldiers, that honour can be gained only through martial deeds.

Soldiering is an important position of Bertram's place and time. Wars are deeds of valour creating opportunities to provide honour to the King, the country and personal reputation. Bertram's supreme desire is to prove worthy of honour to those he considers important to him. He does not need to prove that he has inherited his father's physical characteristics, the "arched brows, hawking eye and his curls" (I.i: 96), but has yet to embody the moral qualities: bravery, courage and martial glory.

One constituent of Bertram's character, stressed extensively throughout the play, surely influences his judgment on his new responsibilities, on his society, and on his selection of the element most susceptible to provide him his aspired existence: his youth.

First lord: "O, my sweet lord, that you will stay behind us!

Parolles: 'Tis his fault, the spark.

Second lord: $O$, 'tis brave wars!

Parolles: Most admirable. I have seen those wars.

Bertram: I am commanded here and kept a coil with

"Too young," and "The next year," and " Tis too early."

Parolles: An thy mind stand to't, boy, steal away Bravely.

(II.i:24-30)

Bertram's father's sudden death had him access wardship too early. The "unseasoned courtier" (I.I: 71) that he is thought to be, by all the respectable authorities of the play, is unprepared to manage his father's estate as he preferred to go to war. His 
callowness only further entices him to live up to his father's reputation as "disciplined of the bravest" (I.II: 28).

There are two perspectives on honour in All's Well That Ends Well: that of Bertram and that of everyone else. For the majority, the code of honour is that of the new Tudor aristocracy; that is, honour is gained by serving the king and refers to public service. In this code, nobility of birth is one important factor for virtue, but there is openness for nobility acquisition. It is available to everyone and conferred by the royal authorities for an extraordinary deed accomplished for public service ${ }^{95}$. All acknowledge true nobility stemming from within the individual. Everyone in the play observes and lives by it, except Bertram.

King:...From lowest place when virtuous things proceed,

The place is dignified by th'doer's deed.

Where great additions swell's, and virtue none,

It is a dropsied honor. Good alone

Is good without a name; vileness is so;

The property by what it is should go,

Not by the title. She is young, wise, fair;

In these to nature she 's immediate heir,

And these breed honor. That is honor's scorn

Which challenges itself as honor's born

And is not like the sire. Honors thrive

When rather from our acts we them derive

Than our foregoers. The mere word's a slave

Debauched on every tomb, on every grave

A lying trophy, and as oft is dumb

Where dust and damned oblivion is the tomb

Of honoured bones indeed. What should be said?

If thou canst like this creature as a maid,

I can create the rest. Virtue and she

Is her own dower; honor and wealth from me.

(II.iii: 125-144)

\footnotetext{
${ }^{95}$ Siegel, "Shakespeare and the Neo-Chivalric Cult of Honor." p. 42.
} 
All then agreed on the fact that moral virtues could be innate for anybody, whether an aristocrat or not. Accordingly, most characters in All's Well That Ends Well, including the respected members of the court, namely the Countess and the King, adhere to this perspective and contemplate honour as an inherent character trait. Hence, they believe that virtue, pride and dignity of one's self deliver their recompense of worth and contentment stemming from these internal sources, in respect and benevolence from honourable others who entrust them. In the Nichomachian Ethics, Aristotle argues that:

If then the great-souled man claims and is worthy of great things, greatness of soul must be concerned with some one object especially. 'Worthy' is a term of relation: it denotes having a claim to goods external to oneself. Now the greatest external good we should assume to be the thing which we offer as a tribute to the gods, and which is most coveted by men of high station, and is the prize awarded for the noblest of deeds; and such a thing is honour, for honour is clearly the greatest of external goods. Therefore the great-souled is he who has the right disposition in relation to honours and disgraces. And even without argument it is evident that honour is the object with which the great souled are concerned, since it is honour above all else which great men claim and deserve. ${ }^{96}$

It is on such an account that Bertram's conception of honour is founded, and thus, differs from everyone else's. As the soldier that he wants to be, his vision is in accordance with the neo-chivalric code of honour. It focuses on "an idealisation of war and duels, and a glorification of death on the fields of honour, and aims on the image that this heroic world attempts to project is that of the hero as a strong man and a great warrior who provides protection and leadership for his family and community ${ }^{97}$. It has nothing to do with the

\footnotetext{
${ }^{96}$ Aristotle, The Nicomachean Ethics. p. 90.

${ }^{97}$ A. MacIntyre cited in Fahmi, "Man's Chief Good: The Shakespearean Character as Evaluator." p. 125.
} 
courtier aspect comprised in the definition of ward as defined when his father was occupying the wardship, and as is understood by the majority in the play ${ }^{98}$.

Ethical choices require serious and appraised discernment. In his argument on virtue, Aristotle mentions wisdom and reason as being dispositions of the mind necessary to adequately determine one's ethical values, define one's highest good, and find the means to attain that good $^{99}$. In order to achieve this, an individual must have character inclinations to justly and reasonably choose what is good and what is not for oneself. This moral reasoning is to be acquired through experience and by drawing valuable lessons from life.

Bertram's interpretation of honour is blinded by his youth and in total opposition to everyone else's concept of honour. For our young protagonist, the idea of honour is constituted primarily of personal martial glory; hence, it becomes the only way to access honour, a good reputation. Consequently, the worthwhile life and acknowledgment from his significant others reside on the battlefield.

Charles Taylor argues that identity and ethics are inseparably intertwined, that knowing the kind of person one wants to be involves both having a particular idea of the good and being ready to embody that idea ${ }^{100}$. This evaluation, though, is made from one's best knowledge and evaluation standards available at that particular time of one's life. Bertram is a "lascivious, foolish idle boy" (IV.iii: 218). Bertram is surrounded and part of a

\footnotetext{
${ }^{98}$ Siegel, "Shakespeare and the Neo-Chivalric Cult of Honor." p. 39-70.

The author argues that in the neo-chivalric code of honour, there is no importance given to public service as there would be in the Christian humanist cult of honor installed in the late Renaissance era. He quotes C.L. Barber's comment from "The Idea of Honour in the English Drama" where honour is "concerned with maintaining the reputation for the personal courage and the spirit sensitive to anything remotely resembling a slight deemed to be proper for a man of birth. Learning tends to be held in contempt as suitable for scholars rather than aristocrats."

${ }^{99}$ Aristotle, The Nicomachean Ethics. p. 141-142.

${ }^{100}$ Taylor, Human Agency and Language: Philosophical Papers. p. 34-35.
} 
group of "unbak'd and doughy youth" (IV.v: 3), servants of a king sending them to war to waste their overflowing energy. Thus, his evaluation and choices stem from the experience that life has provided him so far. The conversations flowing around him provide the standards for which he decides what is of interest for $\operatorname{him}^{101}$ and he appraises them to the best of his knowledge. It is what strikes his inner self as the image he wants to resemble. Consequently, these elements become the reference in the definition of his "background of intelligibility from which he draws the language of articulacy, a language of expression that enables him to articulate his true self ${ }^{102} "$. For Bertram there is no negotiation. To attain the worthwhile life, he must espouse, both physically and morally, the life of a soldier. He must breathe, act and live as a soldier. This will, no doubt, have consequences on his decisions and it will govern his actions.

.... I shall stay here the forehorse to a smock, Creaking my shoes on the plain masonry,

Till honor be bought up, and no sword worn But one to dance with. By heaven, I'll steal away!

(II.i: 27-33)

Bertram's major flaw is his lack of moral criticism. His judgments are based on what is quickly available to him like his social status and wealth. He will not bother to give more reflection on the matter. To fully live his desire, and be a soldier, Bertram must leave the family nest and join his regiment. He is eager to break away from his mother's grip and

\footnotetext{
${ }^{101}$ Fahmi, "Man's Chief Good: The Shakespearean Character as Evaluator." p. 124.

Fahmi argues that the choices made in view of definition of identity are available to the subject by his own culture, the people he meets or the books he reads.

${ }^{102}$ Ibid, p. 124.
} 
prove his worth as a full-fledged man. For him, honour is the ultimate gift of virtue, and age should not be an impediment in its acquisition.

From this point on, Bertram is no longer in dialogue with those who matter but in dispute with the discourse provided to him. The difference between Bertram's conception of honour and that of everyone else around him creates discordance with the language of expression that should allow him to express his aspired self. His actions consequently become misleading and confounding to most of his entourage.

The first controversial action oriented toward Bertram's idea of the good happens in court as Bertram is sacrificed as a husband by the king to virtuous Helena.

King: Why then, young Bertram, take her; she's thy wife.

Bertram: My wife, my liege? I shall beseech your highness, In such a business give me leave to use

The help of mine own eyes.

King: Know'st thou not, Bertram,

What she has done for me?

Bertram: Yes, my good lord:

But never hope to know why I should marry her.

King: Thou know'st she has raised me from my sickly bed. Bertram: But follows it' my lord, to bring me down Must answer for your raising? I know her well; She had her breeding at my father's charge. A poor physician's daughter my wife? Disdain Rather corrupt me ever!

(II. iii: 104-115)

Bertram's act of will is perceived as a monumental faux-pas to everyone else, most especially by the king. He is not only being discourteous towards a lady and disobeying his king's orders but he is also breaking a vow, which does not matter to him. Bertram's life belongs to the king who may dispose of it according to his august wishes. Bertram 
nonetheless goes forth and disobeys the king in front of everyone else, putting him in an awkward position of shame.

King: "My honor's at the stake, which to defeat I must produce my power. Here, take her hand, Proud scornful boy, unworthy this good gift... It is in us to plant thine honor where We please to have it grow.

(II. iii: $148-156)$

The young ward is offered as a token of acknowledgement for Helena's good action. As part of the court's wards, Bertram owes utter respect and obeisance to the royal authority. Not only does the young man refuse to obey his king but he also repudiates the king's honour as well. His first reaction is to refuse marrying Helena because he finds her unworthy of him, to which the king replies with anger:

King: 'Tis only title thou disdain'st in her, the which I can build up. Strange is it that our bloods, Of color, weight, and heat, poured all together,

Would quite confound distinction, yet stands off In differences so mighty. If she be All that is virtuous - save what thou dislik'st A poor physician's daughter - thou dislik'st Of virtue for the name. But do not so.

From lowest place when virtuous things proceed, The place is dignified by th' doer's deed. Where great additions swell's, and virtue none, It is a dropsied honor. Good alone Is good without a name; vileness is so: The property by what it is should go, Not by the title.

(II.iii: 116-130)

The king shows here that not only is Bertram wrong about Helena's unworthiness, but that the king has the power to remedy the situation. Initially, one would be tempted to 
think that, as a spoiled child born into riches, immaturity would be the factor influencing Bertram's judgment, thus having him evaluate worthiness according to social rank and fortune standards. However, in my view it has strictly nothing to do with Helena as such. The point is that life as a married man just does not accord with that of a soldier's. Bertram's discernment of a soldier's life excludes lifetime commitments and faithfulness to one single woman. Without analysing the consequence of his actions, Bertram goes on as he needs to:

Parolles: What? What, sweetheart?

Bertram: O my Parolles, they have married me! I'll to the Tuscan wars and never bed her."

Parolles:... To th'wars, my boy, to th'wars!

He wears his honor in a box unseen that hugs his kicki-wicky here

at home,

Spending his manly marrow in her arms,

Which should sustain the bound and high curvet

Of Mars's fiery steed. To other regions!

France is a stable; we that dwell in't jades.

Therefore to th'war!

(II.iii: 275-280)

Of course, Bertram is a paradigm of exceeding youth resulting in a lack of wisdom. He is a normally constituted young man living in a society where, for men, sexual laxity does not impede on gains of honour. As a matter of fact, it is one way to prove one's masculinity, and Bertram has taken notice of this point. The "foolish idle boy" (IV.iii: 211) has gathered that being a good soldier implies being capable of demonstrating high male values on the battlefields and with women. Even his monarch is explicit about and supportive of this perspective and expresses it clearly to his young lords before they leave to war: "Those girls of Italy, take heed of them" (II.i: 19). These words would, for sure, be 
taken literally by any young man contained by excessive "natural rebellion" (V.iii: 6). After hearing such words, Bertram only responds to the discourse through which he sees the reflection of what he wants to be. Bertram is willing to go to any length to concretize his aspirations and live them fully, which provokes negative impressions from those around him.

Helena: May be the amorous count solicits her in the unlawful purpose.

Widow: He does indeed, And brokes with all that can in such a suit Corrupt the tender honor of a maid:

But she is armed for him, and keeps her guard In honestest defense.

(III.v: 67-75)

The "lascivious young boy" (IV.iii: 302) surely has all the qualities for soldiering. As all soldiers heading to the battlefield, Bertram impetuously discards long-term relationships and faithfulness to one single woman but does not reject sex. For him, love subsumes to a bodily need that can be satisfied wherever he may.

Countess: 'tis past, my liege, And I beseech your Majesty to make it Natural rebellion, done I'th'blade of youth,

When oil and fire, too strong for reason's force $O$ 'erbears it and burns on.

(V.iii: $4-9)$

He does not control this "rebellion" and certainly does not want to control it. Bertram is surrounded by different value models, but his limited skills pertaining to evaluation have him blinded when it comes to moral excellence. "The tracts of honour 
provide evidence that the code considered physical appetites a danger to a soldier's valour, and therefore his honour ${ }^{103}$ ". This statement advises soldiers that dedication to their deeds may be lessened by human desires. In the same views, Bertram's honour is endangered by his sexual instincts, and from the perspective of those who surround him, it very well could be unfavourable to his reputation. He is caught between boyhood and manhood, a space "where love's strong passion is impressed in youth" (I.iii: 129). He shows no respect for women and does not give any thought to what others might think of him.

First lord: He hath perverted a young gentlewoman here in Florence, of a most chaste renown, and this Night he fleshes his will in the spoil of honor....

Second lord: Now God delay our rebellion! As we are ourselves, what things are we!

First lord: Merely our own traitors. And as in the common Course of all treasons, we still see them reveal themselves till they attain to their abhorred ends, so he that in this action contrives against his own nobility, in his proper stream o'erflows himself.

(IV.iii:14-24)

Bertram is a whirlwind of disappointment and deceptions for his significant others.

For them, the boy does not correspond to set expectations. Not only does he disobey the

${ }^{103}$ Council, When Honor's at the Stake: Ideas of Honor in Shakespeare's Plays. p. 41.

Whetstone's 'Honorable Reputation of a Souldier' remarks that "When the body is stuffed with delicates, the mind is dull and desirous of ease, which is the undoer of a Souldier... "One is reminded of the Antony whom Octavius Caesar admired because he, faced with famine, "didst drink /the stale of horses and the gilded puddle / Which beasts would cough at" (I.4:61-63). "And all this", Caesar concludes in comparing the honourable Antony with Cleopatra's Antony, "(It wounds thine honour that I speak it now)/Was borne so like a soldier that thy cheek/So much as lank'd not" (I.4: 68-7I). Worth mentioning is Falstaff's who prefers life and good times to honour on the battlefields. 
king, but now he discredits his heritage and birthright by validating and embodying his ambition. In such designs, he will cover his entourage with shame, making no difference among the individuals. This is in total dissonance with the concept of "shame culture", according to which "the hero's behaviour should be in total accord with the aristocratic culture of honour, in the sense that he must by no means bring shame on his family or community by acting in a disgraceful manner ${ }^{104}$,, either by refusing war or by disobeying authority figures of his society.

Countess: ... He was my son,

But I do wash his name out of my blood, And thou art all my child. Towards Florence is he?

First lord: Ay, madam.

Countess: And to be a soldier?

First lord: Such is his noble purpose, and believe't, The duke will lay upon him all the honor That good convenience claims.

(III.ii: 63-72)

Embodying in totality a role that was his father's is like living up to an idealized figure. The life of a soldier is enough for Bertram to set his identity standards; to act his selected role on the stage of life. From his point of view, there is no need for the 'courtier' aspect of his duty. Even if his behaviour is not perceived as appropriate by others, it is nonetheless Bertram's conception of life, and he pursues his purpose. Bertram has chosen the life of a soldier. In the heat of the moment and in front of his superiors and whole battalion, he proudly proclaims his allegiance as his purpose:

${ }^{104}$ Fahmi, "Man's Chief Good: The Shakespearean Character as Evaluator." p. 125. 
Duke: The general of our horse thou art; and we, Great in our hope, lay our best love and credence Upon thy promising fortune.

Bertram: Sir, it is

A charge too heavy for my strength, but yet

We'll strive to bear it for your worthy sake

To th' extreme edge of hazard.

Duke: Then go thou forth,

And Fortune play upon thy prosperous helm

As thy auspicious mistress!

Bertram: This very day,

Great Mars, I put myself into thy file.

Make me but like my thoughts, and I shall prove

A lover of thy drum, hater of love.

(III.iii:1-11)

Soldiering is undoubtedly his idea of honour and good life. It allows him to articulate his chosen identity and to communicate in accordance or in discordance with others, and thus fashion who he wants to be at the expense of what others may think. Notwithstanding the fact that his judgment is shadowed by his immaturity, Bertram has established the limits of his moral space based on standards available to him at that particular time of his life. From these standards, he evaluates what is good or not, what is worthy or not and, above all, he abides by his choice more in functions of the issues he stands for than on the results of his actions. Bertram adheres to the Taylorian notion of "strong evaluator", an agent who deploys a language of evaluative contrasts ranging over desires $^{105}$. On such an account, Bertram weighs, from ethical appraisals, what is susceptible to lead him to ultimate happiness and thus determines the bases upon which he scaffolds his true self. These appraisals will consequently fashion the actions he needs to take in

${ }^{105}$ Taylor, Human Agency and Language: Philosophical Papers. p. 23. 
contemplation of the worthy existence and to anticipate, to a certain extent, the consequences.

Bertram's selected values and actions have him in a continuous state of confrontation with his entourage, which could lead him to experience an "identity crisis". In conjunction with Taylor's view on strong evaluations, the "identity crisis" may occur in situations where, due to a gap in language of expressions, the meaningful others have failed to comprehend and hence acknowledge the agent's highly-esteemed choice, which happens to be the case with Bertram. Bertram then could face a loss of orientation explained by Taylor as "an acute form of disorientation, which people often express in terms of not knowing who they are, but which can also be seen as a radical uncertainty of where they stand ${ }^{106 \%}$. Those around him know what he is but refuse to approve of the actions he chooses to take for the sake of his ultimate goal. They only have access to his vision of what he wants to be, in reference to Fahmi's argument to the fact that "if Shakespearean characters are as complex as they are believed to be. It is pointless to try to know who they really are. Knowing who a person is is an illusion; the only thing we may know about someone is what he or she wants to be. It is our only access to their identity ${ }^{107}$, . Fahmi also claims that for an action to be understood, it should be assessed in relation with the character's moral orientation. In the current situation, not only do others have an idea of whom Bertram strives to be, but they also anticipate what may become of him once the war is over:

\footnotetext{
106 Taylor, Sources of the Self: The Making of the Modern Identity. p. 29.

${ }^{107}$ Fahmi, "Man's Chief Good: The Shakespearean Character as Evaluator." p. 124.
} 
Second lord: In the meantime, what hear you of these wars?

First lord: I hear there is an overture of peace.

Second lord: Nay, I assure you, a peace concluded.

First lord: What will Count Rossillion do then?

(IV.iii:37-42)

In all evidence, there is no need for soldiers and warriors, in the way Bertram intends it, in the absence of war. Therefore, for one who values the battlefield as purveyor of virtue, without war there is no way to honour. The question is this: How is Bertram to react when he is confronted with the end of war? Situations such as this, where the agent's profound life ambitions are fundamentally questioned, often lead to an identity crisis, a destabilizing concept that forces one to flee or face, depending on the disposition of mind and character, crucial and challenging life encounters. They are events that confront the agent on whether "to be or not to be" and respond according to one's environment. For some Shakespearean characters, such disorientation equals "end of life". For Bertram, eventual peace procures him an opportunity to reconsider his perspective on his true purpose in his society, on his vision of virtue, and consequently on his perception of honour. It provides him with new paradigms allowing him to have a fresh and objective outlook of his aspired self in concordance with his times. It solicits a re-examination of his standpoint in relation to his community's perspectives, and to readjust in respect to them. "The origin of virtue itself is in the dynamic meeting between our ideas of who we are, and the various events and experiences that call those ideas into question ${ }^{108,}$. The process to successfully achieve such ethical changes confirms Bertram's strength of character.

\footnotetext{
${ }^{108}$ Myers, The Other Side of Virtue: Where Our Virtues Came from, What They Really Mean, and Where They Might Be Taking Us. p. 40.
} 
Reconsideration of new options in relation to the world he lives in opens avenues towards his maturity. As Helena shows that, according to the requests in Bertram's letter, she is wearing his ring, she also proves virtuous and worthy of him:

Bertram: If she, my liege, can make me know this clearly, I'll love her dearly-ever, ever dearly.

(V.iii:312-313)

In such events, Bertram amends and fully embodies his responsibilities and inheritance in physical body as in moral shape. 


\section{CHAPTER III}

"Honor neither is risen out of the opinion of the multitude, nor out of the vaine boastinges of men"

Robert Ashley

\section{"Mine Honour Keeps the Weather of my Fate ${ }^{109 "}$ Self- Interpretation and Fame in Troilus and Cressida}

Considered the "comedy of disillusion"110", Troilus and Cressida" is the most atypical of the three Problem Plays under consideration. Here, no bed-tricks are involved. The plot does not stem from folklore or Italian culture. Its conclusion, the most disastrous of the three, differs from its sister-plays by the enigmatic conclusion it leaves for the readers to unravel. Unlike the other two plays, the readers' and critics' questions are not aroused by the ambiguity of its conclusion, but by the plot itself. This play has always suffered because of its complexity. Nonetheless, the play, thought to have been written for aristocratic and educated spectators, is regarded as the "most explicitly learned play that Shakespeare ever wrote ${ }^{112 \%}$.

\footnotetext{
${ }^{109}$ Shakespeare, "Troilus and Cressida."

${ }^{110}$ Thomas, The Moral Universe of Shakespeare's Problem Plays. p. 2.

${ }^{111}$ Bevington, The Complete Works of Shakespeare. P. 460-506.

${ }^{112}$ Stanley W. Wells Kenneth Muir, ed., Aspects of Shakespeare's Problem Plays: All's Well That Ends Well, Measure for Measure, Troilus and Cressida (Great Britain: Cambridge University Press, 1982).
} 
Troilus and Cressida sheds a cynical light on the animus of war and on the extent to which humanity is willing to go for the sake of reputation. From the play's opening and onward the absurdity of war is emphasized:

In Troy there lies the scene. From isles of Greece

The princes orgulous, their high blood chaf'd,

Have to the port of Athens sent their ships,

Fraught with the ministers and instruments

Of cruel war: sixty and nine, that wore

Their crownets regal, from the Athenian bay

Put forth toward Phrygia; and their vow is made

To ransack Troy, within whose strong immures

The ravish'd Helen, Menelaus' queen,

With wanton Paris sleeps; and that's the quarrel.

(Prologue: 1-10)

Evidently, the disproportion between the reason to fight and the resulting carnage and bloodbath is the first conflicting issue disclosed about the play. In Troilus and Cressida is dissonance and divergence at its best: coarse Greek barbarians versus well-spoken Trojan courtiers. This "sneering political pamphlet ${ }^{113 "}$ is about a war in which soldiers have been sacrificing their lives for nothing but a worthless, adulterous Jezebel; this is a war maintained by misplaced pride of ludicrous advocates. The play ends up in derision emphasizing the ridicule of a tragic conflict, leading everyone through a maze of dissidence and contradiction to its very perplexing and mystifying end. The play is in fact avant-garde in the way it corresponds to contemporary social superficiality, where chivalry becomes a pretence to justify the decadence of that superficiality.

113 Jan Kott, Shakespeare Our Contemporary, trans. Boleslaw Taborski (New York: W.W. Norton \& Company, 1974). p. 78 . 
In conjunction with the theme and defining features characterizing the play, the dramatis personae converge in the same sense of absurdity. During an epoch of knights and honor, where magnanimity, courage, justice, and loyalty are prevailing ideals, the characters are contemplated as the antithesis of what real heroes should be. "Menelaus is a cuckold, Helen is a tart, and Achilles and Ajax are buffoons ${ }^{114}$." Here again, contradiction is the key word: every one of these so-called distinguished and honorable members of the Homeric aristocracy, disputing a senseless war, are governed to excess by the preposterous and extravagant notions of chivalry ${ }^{115}$ where courtly love and shallowness of feminine beauty is enough for the slaughter of a nation.

With this in mind, even Hector is no exception. Prior to his entrance on stage, the numerous renderings in the play of his military deeds and benevolence have readers already perceiving him as no less than a valorous and courageous warrior.

Pandarus: That's Hector, that, that, look you, that;

There's a fellow! Go thy way, Hector! There's a brave

Man, niece. O brave Hector Look how he looks!

There's a countenance! Is't not a brave man?

Cressida: $O$, a brave man!

Pandarus: Is a not? It does a man's heart good. Look you

Look you what hacks are on his helmet! Look you yonder, do you see? Look you there, there's no jesting, there 's laying on, take't off who will, as they say. There be hacks!

Cressida: Be those with swords?

\footnotetext{
${ }_{114}^{114}$ Ibid. p. 77.

115 Theodor Meron, Bloody Constraint: War and Chivalry in Shakespeare (New York: Oxford University Press, 1998). p. 6.

The author discusses on several occasions throughout the book the exaggerated notions of chivalry where foolish and absurd challenges were arranged to defend superficial and frivolous designs such as the virtues of a lady over another.
} 
Pandarus: Swords, anything, he cares not; and the devil come to him, it's all one. By God's lid, it does one's heart good.

(I.ii: 194-205)

In this passage, the importance the concept of otherness has on the articulation of one's identity is evident; that is, identity is in relation with others in such a way that one defines his or her ideal life and hence what one wants to become. The Aristotelian idea of "man as a social animal ${ }^{116 ", ~ i s ~ n o t ~ t o ~ b e ~ o u t d o n e . ~ I n ~ t h i s ~ s e n s e, ~ t h e ~ f a s h i o n i n g ~ o f ~ o n e ' s ~}$ identity is not a mere private issue. It is through dialogue or dispute with those around that one determines the defining elements of one's moral space ${ }^{117}$. Hector is presented as the epitome of knighthood of the medieval era, which is an era not so distant from Shakespeare's Renaissance times where medieval traces still linger. ${ }^{118}$ Hence, this is the social context that provides Hector the language he needs to forge himself. Hector is the embodiment of courage and courtesy on the battlefield, ready for fearless combat to death for honor of his king and country. "Shakespeare's characters are merely dramatic

\footnotetext{
${ }^{116}$ Aristotle, Politics: A Treatise on Government, (London: JM Dent \& Sons Itd., 1928), August 24th 2011. (1253A)

"Man is by nature a social animal; an individual who is unsocial naturally and not accidently is either beneath our notice or more than human. Society is something that precedes the individual. Anyone who either cannot lead the common life or is so self-sufficient as not to need to, and therefore does not partake of society, is either a beast or a god."

Aristotle demonstrates that one cannot be without taking otherness into consideration. Surrounding social environment influences the fashioning of one through inevitable interaction.

${ }^{117}$ Taylor, Sources of the Self: The Making of the Modern Identity. p. 27.

The author defines the moral space as the frame or horizon containing the elements of commitments and identifications providing the ability to determine what is good or bad, what is to be endorsed or opposed, that is, the horizon within which one is capable to take a stand.

${ }^{118}$ Brown Watson, Shakespeare and the Renaissance Concept of Honor. p. 11.
} 
reflections of people produced by specific historical conditions ${ }^{119,}$, and thus Hector most certainly is aware of what others around him think of him and surely adheres to this idea. In Greek philosophy, the definition of the warrior morality is:

one where what is valued is strength, courage, and the ability to conceive and execute great deeds, and where life is aimed at fame and glory, and the immortality one enjoys when one's name lives forever on men's lips. The higher moral condition here is where one is filled with a surge of energy e.g., on the battlefield - and access of strength and courage and is able to sweep all before one ${ }^{120}$.

Strength, courage, fame and glory are terms that merge into one single word: honor. Honor, the incontrovertible concept forging ancient societies, was the key component for codes that regulated the population who, in turn, submitted entirely to those codes in their quest for reputation. However, Hector proves to be, as are the rest of the characters, a haven of discrepancy and antinomy when it comes to his reflections versus his actions. In this view, my contention is the following: what urges Hector to jeopardize the life of thousands of Trojans in the name of honor?

As in other works of Shakespeare, one code of honor prevails. Chivalry in Troilus and Cressida takes an outstanding venue since it is the predominant ethical system fashioning the Shakespearian era. Chivalry is a system where moral values such as honor, courage, magnanimity, and loyalty not only transcended the social order and founded laws, but also molded civilization and each individual's actions. "Honor commits men to act as they should... Chivalry's most profound influence lay in just this, in setting the seal of

\footnotetext{
${ }^{119}$ Hawkes in Fahmi, Shakespeare's Poetic Wisdom: Identity, Orientation, and Historical Providence in the Henriad.p. 16.

${ }^{120}$ Taylor, Sources of the Self: The Making of the Modern Identity. p. 117.
} 
approbation on norms of conduct ${ }^{121} \ldots$ "In relation to the idea of otherness as being a fundamental feature for the elaboration of one's identity ${ }^{122}$, the concept of honor is what determines the grounds upon which Hector constructs his identity and forms the genesis from which he "can decide what is good or bad, what is to accept and what is to oppose $\mathrm{e}^{123}$." Consequently, Hector possesses the moral selection comprising the elements susceptible to lead him to the good life from his own perspective. His "moral horizon" conforms to the reality of his time. He is recognized as, and embodies the idea of, the most gallant and bravest of princes as displayed in Aenas' speech:

If there be one among the fair'st of Greece That holds his honor higher than his ease, And seeks his praise more than he fears his peril. That knows his valor, and knows not his fear, That loves his mistress more than in confession With truant vows to her own lips he loves, And dare avow her beauty and her worth In other arms than hers - to him his challenge! Hector, in view of Trojans and of Greeks, Shall make it good, or do his best to do it; He hath a lady, wiser, fairer, truer,

Than ever Greek did couple in his arms.

(I.iii: 264-76)

People then, barely out of the medieval epoch but not quite into the Renaissance, observed a clustered version of the concept of chivalry, where elements of both Greco-Roman ideology and medieval Christianity come into play. In the article "Shakespeare and the Neo-Chivalric Cult of Honor", P.N. Siegel argues that. Shakespeare uses in his work a Renaissance concept of honor, one where the values of two ethical systems were

${ }^{121}$ Meron, Bloody Constraint: War and Chivalry in Shakespeare. p. 11.

${ }^{122}$ Fahmi, The Purpose of Playing: Self-Interpretation and Ethics in Shakespeare. p. 13.

${ }^{123}$ Fahmi, "Man's Chief Good: The Shakespearean Character as Evaluator." p. 122. 
amalgamated into one new conceptual vision: Christian humanism. However, he sustains that major precepts of these systems came in opposition, namely the christian humanist ideal of honor and the neo-chivalric cult of honor. Here, the main conflicting issue is the following: The Christian humanist ideal of honor was derived from courtesy books and ethical philosophy. The idea of the courtier as learned humanistic scholar and the medieval knight values are united in an ideal that regulated the Tudor aristocracy. It stipulated that honor is a moral virtue. The neo-chivalric code of honor stemmed from the chivalric notion of personal military glory where duel in the feudal chivalric tradition and honor is linked more to reputation than it is to virtue ${ }^{124}$. In such vision, Troilus and Cressida is a medievalized account of the Trojan War where Greeks and Trojans fought for Helen of Troy, and where the ideals of chivalry are more mocked than praised.

It is during the discussion with the Trojan War council that readers first encounter the discrepancy between Hector's words and his actions. To Priam, Hector argues that there is no sense in keeping Helen as a war prisoner.

Priam: After so many hours, lives, speeches spent,

Thus once again says Nestor from the Greeks:

"Deliver Helen, and all damage else, As honor, loss of time, travail, expense,

Wounds, froends, and what else dear that is consumed

In hot digestion of this cormorant war,

Shall be struck off." Hector, what say you to't?

Hector: Though no man lesser fears the Greeks than I,

As far as toucheth my particular,

Yet, dread Priam,

There is no lady of more softer bowels,

More spongy to such in the sense of fear,

More ready to cry out "Who knows what follows?

${ }^{124}$ Siegel, "Shakespeare and the Neo-Chivalric Cult of Honor." 
Than Hector is. The wound of peace is surety,

Surety secure; but modest doubt is called

The beacon of the wise, the tent that searches

To th'bottom of the worst. Let Helen go,

Since the first sword was drawn about this question,

Every tithe soul, 'mongst many thousand dismes,

Hath been as dear as Helen; I mean, of ours.

If we have lost so many tenths of ours

To guard a thing not ours nor worth to us

(Had it our name) the value of one ten,

What merit's in that reason which denies

The yielding of her up?

Instead of being clear and consistent by taking a position, Hector begins his reply by stating that Helen should be returned, but then swerves and declares that she could be kept as a hostage. Hector is a prince and this status most certainly gives him the credibility and reliability others may rest upon. Furthermore, he is subject to the code of honor upon which society of that time is built, and as one living and existing through that code, he conforms to it unconditionally. He claims with conviction that there is no point in bloody battle and war casualties over one single woman, and in accordance with the ethos of chivalry where all those not directly concerned by war are to be excluded from it in totality ${ }^{125}$, clearly states that Helen "is not worth what she doth cost /the holding." (II.ii: 51-52). Chivalric ideals proscribed the making of women as war prisoners and Hector's argument pertaining to Helen is logical in that sense. Hector, being who everyone thinks he is, is thus expected

\footnotetext{
${ }^{125}$ Honoré Bouvet in Meron, Bloody Constraint: War and Chivalry in Shakespeare. p. 140.

Bouvet supports that "According to the ancient custom of good warriors, it is an unworthy thing to imprison either old men taking no part in the war, or women, or innocent children. Certainly it is a very bad custom to put them to ransom as it is common knowledge that they can have no part in war, for the former lack strength, the others knowledge. And in truth to capture them would show no great courage, for all gentlemen should keep them from harm and all knights and men-at-arms are bound to do so, and whoever does the contrary deserves the name of pillager."
} 
to react in such a way. Again, as a figure of authority, Hector's status requires that he display magnanimity and benevolence with whomever he interacts. He is aware of the fact that there is no place for women in wars, and consequently women should not be held as ransom. His insistence against the idea that one abide by his position at all times even if in error, has an emphasizing effect on his credibility and persuasion.

"Thus to persist

In doing wrong extenuates not wrong

But makes it much more heavy."

(II.ii: 186-188)

Hector shows consistence in establishing his point of view. However, at the moment where Hector has convinced everyone that Helen should be returned to her people, a radical change occurs in him:

\section{...Hector's opinion}

Is this in way of truth; yet ne 'ertheless, My spritely brethren, I propend to you In resolution to keep Helen still;

For 'tis a cause that hath no mean dependence Upon our joint and several dignities.

(II.ii:188-193)

The inconsistency that Hector shows is directly related to the concepts of virtue present in his time. As a prince, Hector is assumed to represent the virtues existing in Hellenic times, where "the basic values of society were given, predetermined and so were a man's place in the society and the privileges and duties that followed from his status ${ }^{126,}$

${ }^{126}$ M.I. Finley in MacIntyre, After Virtue. p. 115. 
and consequently, Hector is destined to a "given role and status within a well-defined and highly determinate system of roles and statutes". The idea here is that social hierarchical structures are determined by lineage and the place one occupies within the household. Being not only a prince but also the oldest son of King Priam and heir to the throne, Hector, as everyone else within any heroic society, is aware and fully embraces his obligations towards others. Furthermore, Hector is aware of others' obligations towards him where the obligations depend on where these others stand within the social hierarchy. This is, in all accounts, a society where "a man is what he does; where a man and his actions become identical, and he makes himself completely and adequately comprehended in them ${ }^{127 "}$. Thus actions of individuals were in accordance with this idea: man is his actions and all were expected to act in relation with their social worth. Consequently, Hector makes sense of himself through the expectations of his society; the just, courageous, and magnanimous man that he is; the orders that he submits to, and the rules and notions that his status imposes on him. This submission is crucial for him to retain his high position within the social structure of his time and, accordingly, Hector's moral framework is embedded in these social premises. However, Hector's situation is far more complex than it seems. In addition to being a prince, Hector is also a Hellenistic virtuous warrior and without any doubt, submits to specific notions that this role asks of him.

Hector's conception of self follows two concepts: his "sense of respect for and in obligations to others and his understanding of what makes a full life" as argued by Charles Taylor in his book, Sources of the Self where he expounds that "morality" not exclusively

${ }^{127}$ E.Fränkel in MacIntyre, After Virtue. p. 115. 
in terms of deference to others. He divides moral thinking into three axes focused on the following concepts: our sense of respect for and in obligations to others, our understanding of what makes a full life, and our sense of dignity, three axes upon which an individual takes reference to set the limits and determine his moral space ${ }^{128}$. Accordingly, Hector then aspires to be in conformity with these concepts and, in this view, his evaluations will inevitably be influenced by them as they are influenced by the social concepts surrounding Hector. "Homeric heroes are defined by the bravery and honor they show in wars, where "dying thus less of an evil than being shamed and losing face" as argues Moses Finley ${ }^{129}$. He explains that, in Homeric times, there was no place for peace negotiation. Once the war machine was started, stopping it without a resounding triumph was considered a dishonor for the nation. It was necessary to show some sort of fulfilling result for the efforts provided by the warriors. It is inconceivable for these heroes to bring shame upon themselves, but to bring it upon a whole country and its people must be avoided at all costs since it is tantamount to a dishonorable death. For them to bring shame upon oneself is inconceivable, but to bring it upon a whole country and its people is insurmountable. Again, honor is related to otherness in the concept of a nation; a nation is a social entity and individuals are, first and foremost, integral parts of this entity. As the influential authority figure in his community, Hector maintains his honor and reputation through his civil contributions. For such reasons, the motives for war become futile and victory must be achieved. Hector has to maintain two statuses: one as prince and governing figure of the Trojan people, and one as the great Hellenistic warrior. Both statuses comprise sets of

\footnotetext{
${ }^{128}$ Taylor, Sources of the Self: The Making of the Modern Identity. p. 15.

${ }^{129}$ Moses Finley in Meron, Bloody Constraint: War and Chivalry in Shakespeare. p. 70.
} 
values that are, from one status to the other, generally comparable; both positions require values such as courage and magnanimity. Hector must embody all of the values in order to identify himself as a prince and as a valorous warrior of the Homeric era. His duty is to avoid, for his people, the Homerically shamed culture where:

...failure, in peace and especially in war, is decried as shameful. ... where intentions are unimportant and where it is defeat in war that is shameful. Skill and courage, the qualities that secure survival, are most highly regarded and public perceptions are the most important. The recognition that defeat in war would result in killing, torture or slavery was a powerful motivation ${ }^{130}$.

Hector must observe the responsibilities as a mark of respect towards his nation which has prescribed duties on him through his status. For these reasons, he weighs both alternatives and chooses to keep Helen captive and, in doing so, avoids the dishonor his country would have felt at its loss of face. Hence his change of heart most certainly shows that he definitely adheres to Taylor's first two axes of thinking which have a crucial impact on the fashioning of Hector's moral space. He knows what to do to protect his fellow countrymen because he knows who he is, and he accepts who he is.

In order to understand Hector's motivations, it is crucial to consider the place hierarchy occupied in Homeric societies. The idea is clearly expounded by Ulysses in Troilus and Cressida:

Ulysses: What honey is expected? Degree being vizarded, Th'unworthiest shows as fairly in the mask.

The heavens themselves, the planets, and this center

Observe degree, priority, and place,

\footnotetext{
${ }^{130}$ Meron, Bloody Constraint: War and Chivalry in Shakespeare. p. 71.
} 
Insisture, course, proportion, season, form,

Office, and custom, in all line of order.

...In evil mixture to disorder wander,

What plagues and what portents, what mutiny,

What raging of the sea, shaking of earth,

Commotion in the winds, frights, changes, horrors,

Divert and crack, rend and deracinate

The unity and married calm of states

Quite from their fixure? $O$, when degree is shak'd,

Which is the ladder of all high designs,

The enterprise is sick......

The primogenity and due of birth,

Prerogative of age, crowns, scepters, laurels,

But by degree, stand in authentic place?

Take but degree away, untune that string,

And hark what discord follows......

(1.iii:83-110)

In this passage, Ulysses convincingly discusses the role of hierarchy in a system and the chaos resulting from the lack of it. As stated earlier in this paper, Heroic society's basic ideals were pre-determined by the concepts of honor and virtue. These communities were governed by laws and rules stemming from these ideals, and thus good men were to act according to these laws and rules to gain distinction and honor from others. Men's actions were appraised by others in correlation with the laws of the community and in relation with each individual's social status. The deeds to be done were in concordance with each individual's social status. Hector is "locked into a given place, role and station that was properly his and from which is it almost unthinkable to deviate ${ }^{131 \%}$. Then as one observing and living by these precepts, one whose reputation is built pursuant to these, he would indubitably act according to them. Hector is to accomplish particular deeds in relation to his particular prominence and in accordance with the prestige and degree of his position. To

${ }^{131}$ Taylor, The Malaise of Modernity. p. 3. 
fully concretize what is expected from his place in the social hierarchy and to fulfill how others perceive him, Hector must be consistent with his obligations. This corresponds to Taylors's concept stating that:

My discovering my own identity doesn't mean that I work it out in isolation, but that I negotiate it through dialogue, partly overt, partly internal, with others... My own identity crucially depends on my dialogical relation with others ${ }^{132}$.

In all events, the social dialogue undoubtedly influences Hector's self-definition in a crucial way. The concepts of his society are a crucial part of the dialogue which inspire Shakespearian characters in their quests for their identities, and from which their background of intelligibility is established. Only from this perspective can Hector, as any other Shakespearian character, decide what is good or bad, what he is to accept or oppose $^{133}$. The social values of his epoch shape his moral background and provide him with the language to engage dialogically with others around him: a rich language of expressions that will allow others to fully understand what he wants to be. By acting in agreement with his social position, Hector provides the necessary standard for others to judge the appropriateness of his actions and validate his virtues and flaws.

As a Shakespearian knight, Hector is to exude anticipated virtues such as courage, justice, generosity, nobility, and magnanimity. Not only is it an obligation and a duty for Hector to live by that code and to embrace it as an integral part of his role in relation to his society, it is also a concept ingrained in his character and thus an integral part of his

\footnotetext{
${ }^{132}$ Taylor, Human Agency and Language: Philosophical Papers. p. 45-46.

${ }^{133}$ Fahmi, The Purpose of Playing: Self-Interpretation and Ethics in Shakespeare. p. 29.
} 
identity. Hector must then conform to each knightly virtue to show his worthiness pertaining to his status as a Homeric soldier and prince, which is what symbolizes his vision of the good. By seeing himself as a Homeric soldier, he gives his life a direction towards a purpose that he judges higher than others, towards his exclusive conception of the ultimate life.

Hector is, for sure, the archetype of accomplished "knight in shining armor", and he will observe every principle pertaining to his rank and the maintenance of his prestigious notoriety.

But value dwells not in particular will, It holds his estimate and dignity As well wherein 'tis precious of itself As in the prizer.

(II.ii: 53-56)

The Trojan prince is quick to display those qualities of worth assigned to his status. He likes to show, through his actions and speech, virtue of character. For Hector, worth of a man stems from within the individual; that is, Hector thinks worth is not solely dependent on the perception of the people around him. Even if he argues that virtue is most valuable when it stems from the inner self rather than from external praises, Hector is nonetheless susceptible to people's kudos. For him honor and reputation are inseparable concepts since "Honor is conferred by one's peers and without honor a man is without worth" ${ }^{134 "}$. Consequently, Hector's concerns focus more on how he behaves in public and how his behaviour is interpreted by others, and this, most definitely, influences his perspective of honor. Theoretically, Hector may be considered a man of character in the way he displays, with no hesitation whatsoever, moral virtues such as courage, integrity, and magnanimity in

\footnotetext{
${ }^{134}$ MacIntyre, After Virtue. p. 118.
} 
specific situations. He is renowned as most benevolent even on battlefields, sparing the defeated:

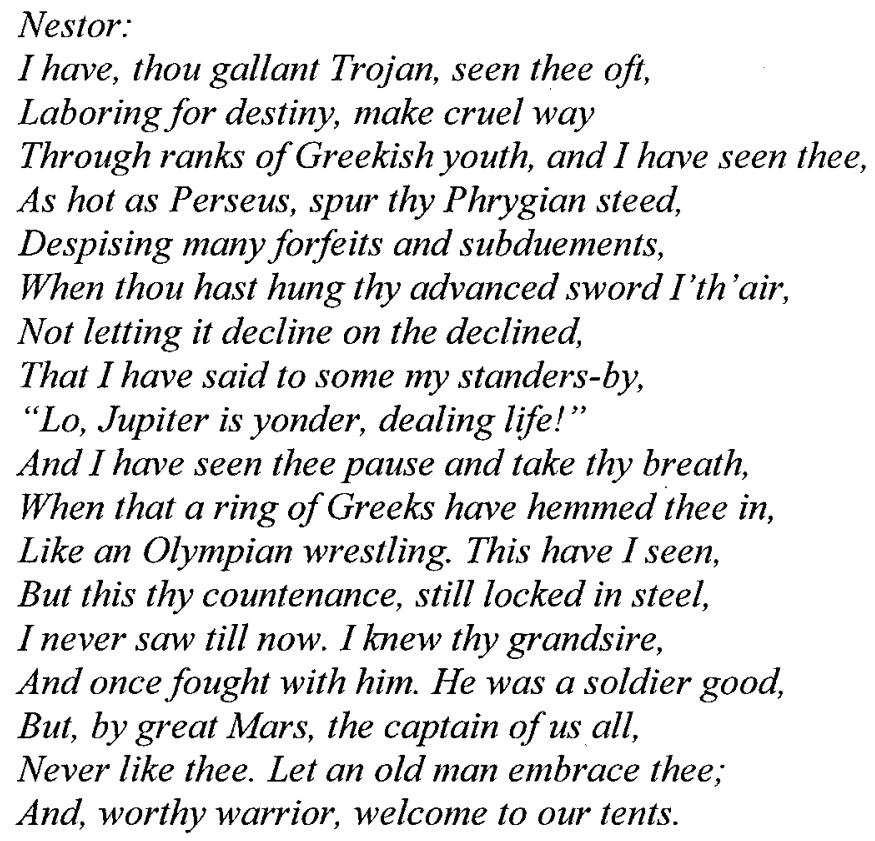

(IV.v: 182-200)

Nestor's' words become a source from which Hector not only receives the expectations of others, but also provides him with the foundations on which he builds his identity. Hector inevitably models his 'self' from his dialogical relation with his society. Indeed, dialogue here is a most crucial referent for the Trojan warrior; he is virtuous, for sure, in spite of the intensity that otherness has on him. Virtues are strengths, as Aristotle argues and, thus strengths of character are essential to a good life. Hector needs and does show that he possesses these virtues. He has been raised a prince and a Trojan warrior, and has developed virtues in accordance to his upbringing. He must oblige to the expectations of those who count on him, namely his family and the population of Troy, to justify the presence of great moral character seen by others in him. Again, Hector focuses more on other's impression of him than on his own preference. It is interesting to note that Hector 
never gives into introspection to consider his notions of honor - his idea of a good life ${ }^{135}$.

In this view, the following excerpt is quite revealing:

Agamemnon: Tis done like Hector.

Achilles: but securely done,

A little proudly, and great deal misprizing

The knight opposed"

Aeneas: If not Achilles, sir,

What is your name?

Achilles:If not Achilles, nothing.

Aeneas: Therefore Achilles. But, whate'er, know this:

In the extremity of great and little

Valour and pride excel themselves in Hector;

The one almost as infinite as all,

The other blank as nothing. Weigh him well,

And that which looks like pride is courtesy.

This Ajax is half made of Hector's blood,

In love whereof half Hector stays at home;

Half heart, half hand, half Hector comes to seek

This blended knight, half Trojan and half Greek.

(VI.v: 73-87)

Excellence, in the Aristotelian concept, is a mean between two vices ${ }^{136}$. In regards to this view, Hector might have a tendency to lean toward one mean - in this case, pride more than its counterpart, shame. The young Trojan prince is renowned for his unwavering,

${ }^{135}$ Troilus and Cressida is the only play where there are no soliloquies.

${ }^{136}$ Aristotle, The Nicomachean Ethics. p. 39.

"Virtue then is a state of character concerned with choice, lying in a mean, i.e. the mean relative to us, this being determined by a rational principle by which the man of practical wisdom would determine it. Now it is a mean between two vices, that which depends on excess and that which depends on defect; and again it is a mean because the vices respectively fall short of or exceed what is right in both passions and actions, while virtue both finds and chooses that which is intermediate. Hence in respect of what it is, i.e. the definition which states its essence, virtue is a mean, with regard to what is best and right an extreme." 
noble pride which he endorses fully. In fact, he is so subjugated by what others think and want from him, that he completely dismisses his own preferences of moral values.

Similarly, Aristotle continues to define "arête" as an exceptional strength for purpose, an innate facility to designate which deed is entitled to moral approval or condemnation and that these constituents demand the discernment of a person of virtue ${ }^{137}$. His argument describes a person of good moral character who can decide with regularity and reliability what deeds are suitable and justifiable in dangerous situations, and when to defend goods and possessions for him or others. Pertaining to Hector, one would be tempted to conclude that he tends more towards one side of the balance than the other, in this case towards pride. Hector is without any doubt a proud man whose values are founded on external concepts. His conception of the self is based on a "heroic" notion of identity in the sense that:

Identity in heroic society involves particularity and accountability. I am answerable for doing or failing to do what anyone who occupies my role owes to others and this accountability terminates only with death. I have until my death to do what I have to do. Moreover this accountability is particular. It is to, for and with specific individuals that I must do what I ought, and it is to these same and other individuals, members of the same local community, that I am accountable.

The heroic self does not itself aspire to universality even although in retrospect we may recognize universal worth in the achievements of that self ${ }^{138}$.

Hector pursues honor in a very singular way: he leans towards the sort of honor which prevails only in the sense that it is "formed in th'applause of other men" (III.iv:119). From his perspective, being in dialogue with others takes on a specific importance; he needs to feel complete agreement with others to be satisfied, which is not necessarily in

${ }^{137}$ Aristotle, The Nicomachean Ethics. p. 71-72.

${ }^{138}$ MacIntyre, After Virtue. p. 119. 
accordance with Aristotelian views. His actions follow closer to his own concept of honor rather than the definition of the virtuous man, where one is deemed honorable since he does deeds of valor with the right intentions of considering the good of others ${ }^{139}$. For instance, numerous demonstrations of chivalric clemency provided by Hector are contradictory:

Troilus: Brother, you have a vice of mercy in you, Which better fits a lion than a man.

Hector: What vice is that? Good Troilus, chide me for it.

Troilus: When many times the captive Grecian falls,

Even the fan and wind of your fair sword,

You bid them rise and live.

Hector:

$O$, 'tis fair play.

(V.iii: 37-42)

Here, Hector's actions are motivated for the wrong reasons; his actions do not focus on the principles of humanity. Indeed, he shows chivalric mercy for the enemy, but it serves his own honor. He will let the enemy live, and this has notable impact on others' perception of him. However, Hector's sense of mercy is divergent because it does not apply to everyone equally; he spares some in the heat of battle and conversely slays a Grecian soldier exclusively for something futile as armor:

Hector: I like thy armor well;

I'll frush it and unlock the rivets all

But I'll be master of it.

(V.vi: 28-30)

\footnotetext{
${ }^{139}$ Myers, The Other Side of Virtue: Where Our Virtues Came from, What They Really Mean, and Where They Might Be Taking Us. p. 99.

Myers argues that a cause is truly noble when it aims to change the world in some great or small way, into a condition better suited for human flourishing.
} 
For many around him, Hector is more committed to public reputation than he is to authentic honor as he should be according to the Aristotelian notion of honor. The Hellenic knight's motivations are more directed towards enhancing his reputation. He assigns extreme importance to what others see in him and think of him. It is his way to "negotiate his identity in dialogue with others since it crucially depends on one's dialogical relations with others ${ }^{140}$. His perception of honor and his pledge to pride enhance his quixotic behavior in fame and hierarchy as well. For instance, the man of noble birth that he is, Hector will not debase himself to fight regular warriors on the battlefield, in accordance with the neochivalric concept of honor ${ }^{141}$. He will not hesitate to ask Thersites:

Hector: What art thou, Greek?

Art thou for Hector's match?

Art thou of blood and honor?

(V,iv ;25-26)

He then evaluate whether his effort of fighting and killing Thersites is worthy of his grandeur.

"Valour and pride excel themselves in Hector... and that which looks like pride is courtesy" (IV.v: 79-82). To others, Hector's honor exceeds the standards of the Aristotelian definition of honor as a reasoned, internal virtue impelling a man to noble deeds, and into a

${ }^{140}$ C. Taylor in Fahmi, "Quoting the Enemy: Character, Self-Interpretation, and the Question of Perspective." p. 132

${ }^{141}$ Siegel, "Shakespeare and the Neo-Chivalric Cult of Honor." p. 41

Neo-chivalric honor is not concerned with public service. It is concerned with maintaining the reputation for the personal courage and the spirit sensitive to anything remotely resembling a sight deemed proper for a man of birth. In this sense, the man of noble birth might refuse to fight a mere gentleman. 
sense-centered external show stemming from attributes conferred by others. This view, however, is the kind of information available to external observers. Information such as color, gender and social status might be interesting to know, but has only partial bearing on the way one makes sense of one's own character from a first-person point of view ${ }^{142}$. However, this does provide an interesting insight into what others think of Hector in comparison to his conception of his identity. For Hector, honor and nobility are gained through merit, and are not as valuable if obtained only from birth. As merit is defined as claim to respect and praise, it is unconditionally and inescapably unattainable without dialogue with others. For a noble personage as Hector, "honor is conferred by one's peers and without honor a man is without worth ${ }^{143 "}$. No matter what others might think of him, is how he conceived himself is what is important. Hector builds his identity according to the dialogue circulating around him. He wants to be a chivalric, princely warrior and the words diffused around him suit him just fine. To interpret himself, Hector does not have to exist in accordance with how others see him.

As a most courageous and noble role, Hector's honor relates to what he does as much as to what he says. Accordingly, oaths and promises are of utmost precedence in the prestigious status that Hector occupies. Hector is quite aware that his words weigh heavily reputation-wise, and that he is valued as an honorable man by others according to his words as much as his actions. He knows that whatever he declares will be contemplated with extreme seriousness and will affect others' perception of him. Therefore when he claims "... The gods have heard me swear" (V.iii: 15), he will do what he ought to in order to justify his words. Excellence in reputation is a key factor defining Hector's identity. In the

${ }^{142}$ Fahmi, "Quoting the Enemy: Character, Self-Interpretation, and the Question of Perspective." p. 132.

${ }^{143}$ MacIntyre, After Virtue. p. 118. 
view of the Aristotelian concept of extremes ${ }^{144}$, the elements directing Hector's choices toward the good life are high reputation versus loss of reputation. Hector's medievalized vision of honor is in accordance with the neo-chivalric cult of honor which stipulates that "breaking one's word was the highest of disgrace ${ }^{145}$. Breaking an oath is the most direct way to irreversibly damage this precious, cherished reputation, so crucial in the scaffolding of his identity.

Cassandra: It is the purpose that makes strong the vow, But vows to every purpose must not hold.

(V.iii: 23-24)

Those who count in Hector's life know that reasons to respect an oath or vow, or fulfill a promise, are not reasons worth dying for. To others, his misplaced pride and exaggerated sense of hierarchy and fame is a source of confusion and dissonance, but it is nonetheless the way Hector makes sense of himself. Hector equates the good life with an honor of his making and will go to all lengths to maintain it, and make his life worthy of admiration and imitation.

Mine honour keeps the weather of my fate;

Life every man holds dear; but the dear man

Holds honour far more precious - dear than life.

(V.iii: 26-28)

Evidently, honor and reputation is to live and die for, in Hector's view. According to the Aristotelian definition of character and "virtuous man", Hector's behavior may be

\footnotetext{
${ }^{144}$ Aristotle, The Nicomachean Ethics. p. 43.

${ }^{145}$ Siegel, "Shakespeare and the Neo-Chivalric Cult of Honor." p. 57.
} 
seen as the epitome of contradiction and inconsistency. Character-wise, Hector demonstrates a certain lack of reflection when it comes to deciding on the appropriateness of certain actions. Being courageous certainly does not mean putting one's self at risk in order to be recognized as a virtuous, reputable man. But, wanting to be recognized as someone in particular implies that we possess a specific image of the good, and that image is what we strive to embody ${ }^{146}$. Inflated pride, with everything it supposes, is how Hector's thinks he can acquire happiness, define his idea of the good life and entirely justify his actions. He will even go as far as disobeying his king-father to achieve this ideal, which he finds integral to his way of life.

Priam: Come, Hector, come; go back. Thy wife hath dreamt, thy mother hath had visions, Cassandra doth forsee, and I myself Am like a prophet suddenly enrapt To tell thee that this day is ominous:

Therefore, come back.

Hector: Aeneas is afield; And I do stand engaged to many Greeks, Even in the faith of valor, to appear

This morning to them.

Priam: Ay, but thou shalt not go.

"I must not break my faith.

You know me dutiful; therefore, dear sir, Let me not same respect, but give me leave

To take that course by your consent and voice Which you do here forbid me, royal Priam,

(V.iii: 71-75)

Hector, in his all chivalric behavior, will "ask his prince for permission to duel,

${ }^{146}$ Fahmi, "Quoting the Enemy: Character, Self-Interpretation, and the Question of Perspective." p. 132. 
but... not obtaining it, shall without license go unto the place of Combat, and with Armes answere the Enemie; for the obligation of honor is to bee proffered before all other ${ }^{147 "}$. Consequently, he will not tolerate any obstacles that could keep him from enacting his specific image of the good. Thus, even if according to true Aristotelian virtue, where honor should be achieved with the welfare of his people in mind, it is hardly the case here. For Hector, HIS honor is HIS concern and therefore when his honor is at stake, he will not let himself be convinced to step out of a duel merely to remain alive.

For those around Hector, drawing judgments and conclusions on the Trojan prince's difficulties to decipher real honor from superficial fame is an easy deed. Hector's discernment pertains to his reputation and thus his identity, which is much more complex than it tends to become from other's perceptions. The fact is that individuals living in a heroic age have no ability for objective perspective ${ }^{148}$. This explains why it is impossible for Hector to imagine his identity, or what he strives to be apart from his princely, chivalric, not to say quixotic, reputation and what makes this reputation a personal affair to be defended by him alone. To make sense of himself out of this framework is a sure way to vanish, to face the identity crisis, and this at the expense of facing death. Yes, Hector interprets his identity in accordance with his surroundings and with the people in his society, but not at the expense of his pride and self-respect.

For Hector, life is not just to be born a prince and be a high aristocratic figure of his Homeric times, but also a prince that protects his people, and does not rely on others to sustain his honor. It is the only way that Hector aspires to the good life.

\footnotetext{
147 Siegel, "Shakespeare and the Neo-Chivalric Cult of Honor." p. 44.

${ }^{148}$ MacIntyre, After Virtue. p. 119.

The author mentions that "to detach oneself from any particular standpoint ... to step backwards and view and judge that standpoint from the outside".
} 


\section{CONCLUSION}

In this thesis, I tried to show how the protagonists of the problem plays take positions according to their notions of good, which they evaluated as the worthiest and highest goals of all. In the process, an explanation was provided for the actions they were willing to take, no matter how questionable those actions may be. These actions are taken to insure that their notions of the good would lead them to happiness. I have attempted to decipher the way each chosen character interprets his or herself through those who matter to them.

My goal was to account for Isabella's, Bertram's and Hector's capacity is to act and, by doing so, justify that what is perceived as confronting behaviour on their part is in fact, a composed, meditated, and considered act. For all three characters, a complex ethical evaluation of priorities derives from their individuality and personal characteristics, in respect to moral boundaries modeled by their distinctive societies and times and to honour as it is understood individually and socially. In addition, I attempted to show how strength of character influences their decisions. Thus, we have seen how these characters pursue the element susceptible to bring them the good life.

In the first chapter, Isabella is ready and willing to sacrifice her brother's life for the sake of what she considers her higher good, namely her chastity. For sure, as a young 
novice about to take her vows, chastity is among her major concerns, but her motivations stem from a place much deeper than mere social status. For her, honor as the result of virtue, is the determining constituent influencing her actions. On these grounds, she interprets her identity in respect to two particular ideas of honor: from the Renaissance features of correct social behaviour, and from inner awareness of honor. She is aware that she must live in accordance to the social standards of her society to establish the reputation contemplated by all and to be seen as the model of moral rectitude not only for herself but for lineage and upcoming generations.

In Isabella's case, inner awareness pertaining to virtue and its reward - honor must be taken seriously. As she shows a propensity to stable character traits, she is naturally inclined towards righteousness and virtue. Accordingly, chastity exceeds the physical state; it is embedded within herself, part of her identity. She contemplates chastity as the ultimate symbol of virtue and consequently honour, in reference to women, as perceived in the society she lives in. She identifies with chastity. On account of this, and she being a nun, she will live and behave as she is expected, and will act in accordance to her status, as it is the vehicle leading her to her vision of the good life.

In the second chapter, Bertram's notion of honour is defined from the knowledge of his young age. His understanding of honour resides in the most apparent aspect of virtue and honour, the kind acquired through military deeds. In that sense, marriage, even if it is prescribed by his monarch, is not an option. His higher good and ticket to the good life reside in what he is destined for and what is expected from him through the inherited public 
role left by his reputed and reputable father, of which Bertram is to assume. This, of course, implies fulfilling the virtuous actions attached to this role of ward to the king.

For Bertram, the role of ward consists in protecting the king and everything related to him: his country, his subjects, his people. For this reason, in his young mind the only way to prove worthy of his inherited position is through soldiering. For him, being ward to the king extends to military deeds exclusively; the role is not concerned with virtues such as magnanimity, and obedience is linked with military service only; compliance with any other sorts of wishes, whatever they may be, even those ordered by his monarch are not worthy of honour. Soldiering is literally taken for what it is; bravery and courage on the battlefield. From Bertram's perspective, soldiering is what will provide him the good life. He shall not hesitate to sacrifice his life to achieve this task and, by doing so, earn the sought-after and so desired honour and peer esteem.

When he finally realizes that behind the evidence of courage and bravery of soldiering there is also loyalty and devotion to the king's desires regardless of what they are, Bertram will show character and his "great-souled man" attitude by conforming to these royal desires, notwithstanding his youth.

In the last chapter, the Aristotelian concept of 'man as a social animal' is strongly emphasized in the case of Hector. The evidence of how otherness impacts one's identity elaboration, how society precedes the individual, and how one becomes who he is through others' perception is clearly shown. Accordingly, Hector is molded from his society's recognition of worth. His perspective of honour resides in reputation and its protection. He 
is the "bravest of princes" and will do what is necessary to live in accordance to the definition of a Homeric hero.

Hector's actions are motivated by what his society expects from his status: his place within the social hierarchy, the legal code governing it, and the obligations towards his nation. As one of character, he will be committed to strive towards these objectives to reach his ultimate goal: what he considers the good life no matter the cost.

Reading Shakespearian characters in terms of self-interpretation is by no means limited to the problem plays. It can be applied to a large number of plays, especially to the tragedies and the histories because the characters in these plays seem to be more complex and more rounded than those in the comedies.

As in Mustapha Fahmi's reading of the Henriad, my reading of the Problem plays shows why the characters will not hesitate to go to extremes to attain the goal of their higher good and reflect the importance of what makes life worth living. Reading Shakespeare's characters this way will allow us, I think, not only to make sense of their actions, but also of the way in which they "author" their own identities. 


\section{BIBLIOGRAPHY}

Aristotle. The Nicomachean Ethics. New York: Oxford University Press, 1980. Print.

---. Politics: A Treatise on Government. 1928. August 24th 2011.

Bevington, David. The Complete Works of Shakespeare. 5th ed: Pearson Longman, 2004. Print.

Bloom, Harold. Modern Critical Interpretation: William Shakespeare's Measure for Measure. New York: Chelsea House Publishing, 1987. Print.

---. Shakespeare: The Invention of the Human. New York, NY: Riverhead Books, 1998. Print.

Bristol, Michael, D., ed. Shakespeare and Moral Agency. London: The Continuum International Publishing Group, 2010. Print.

Brown Watson, C. Shakespeare and the Renaissance Concept of Honor. New Jersey: Princeton University Press, 1960. Print.

Coleridge, S.T. Coleridge's Criticism of Shakespeare. Continuum International Publishing Group, 1989. Print.

Council, Norman. When Honor's at the Stake: Ideas of Honor in Shakespeare's Plays. London: Harper \& Row 1973. Print.

Dillon, Robin S., ed. Dignity, Character, and Self-Respect. London (UK): Routledge, 1995. Print.

Fahmi, Mustapha. "Man's Chief Good: The Shakespearean Character as Evaluator." The Shakespearean International Yearbook. Eds. Bradshaw, Graham and Tom Bishop. Vol. 8. Hampshire, England: Ashgate, 2008. 119-35. Print.

---. The Purpose of Playing: Self-Interpretation and Ethics in Shakespeare. Québec: Two Continents Publishing, 2008. Print.

---. "Quoting the Enemy: Character, Self-Interpretation, and the Question of Perspective." Shakespeare and Moral Agency. Ed. Bristol, Michael, D. London: The Continuum International Publishing Group, 2010. 129-41. Print. 
--.- Shakespeare's Poetic Wisdom: Identity, Orientation, and Historical Providence in the Henriad. Cap-Rouge: Two Continents Publishing, 2003. Print.

Fernie, E. Shame in Shakespeare. London: routledge, 2002. Print.

Foucault, M. Histoire De La Sexualité Ii: L'usage Des Plaisirs. France: Éditions Gallimard, 1984. Print.

Gleed, Paul. All's Well That Ends Well. Bloom's Shakespeare through the Ages. Ed. Bloom, Harold. New York: Bloom's Literary Criticism, 2010. Print.

Kamps, I, Raber, K. Measure for Measure: Texts and Contexts. Boston: Bedford/ StMartin's, 2004. Print.

Kenneth Muir, Stanley W. Wells, ed. Aspects of Shakespeare's Problem Plays: All's Well That Ends Well, Measure for Measure, Troilus and Cressida. Great Britain: Cambridge University Press, 1982. Print.

Kott, Jan. Shakespeare Our Contemporary. 1964. Trans. Taborski, Boleslaw. New York: W.W. Norton \& Company, 1974. Print.

MacIntyre, Alasdair. After Virtue. Notre Dame: University of Notre-Dame Press, 1981. Print.

Major, J. Russell. From Renaissance Monarchy to Absolute Monarchy: French Kings, Nobles, \& Estates. Baltimore: The Johns Hopkins University Press, 1994. Print.

Meron, Theodor. Bloody Constraint: War and Chivalry in Shakespeare. New York: Oxford University Press, 1998. Print.

Myers, Brendan. The Other Side of Virtue: Where Our Virtues Came from, What They Really Mean, and Where. They Might Be Taking Us. O Books, 2008. Print.

Price, J. G. The Unfortunate Comedy: A Study of All's Well That Ends Well and Its Critics. Toronto: University of Toronto Press, 1968. Print.

Shakespeare. "All's Well That Ends Well." The Complete Works of Shakespeare. Ed. Bevington, David. New York: Pearson Longman, 2004. 374-413. Print.

-.-. "The First Part of King Henry the Fourth." The Complete Works of Shakespeare. Ed. Bevington, David. New York: Pearson Longman, 2004. 787-825. Print.

---. "Measure for Measure." The Complete Works of Shakespeare. Ed. Bevington, David. New York: Pearson Longman, 2004. 418-54. Print. 
---. "Troilus and Cressida." The Complete Works of Shakespeare. Ed. Bevington, David. New York: Pearson Longman, 2004. 460-506. Print.

Shalvi , Alice. "The Relationship of Renaissance Concepts of Honour to Shakespeare's Problem Plays." Univertität Salzburg, 1972. Print.

Siegel, P.N. "Shakespeare and the Neo-Chivalric Cult of Honor." The Centenial Review of Arts and Science 8.1 (1964): 39-70. Print.

Taylor, Charles. Human Agency and Language: Philosophical Papers. Cambridge: Cambridge University Press, 1999. Print.

-... The Malaise of Modernity. Concord: Anansi, 1996. Print.

--.. Sources of the Self: The Making of the Modern Identity. Cambridge: Hardvard University Press, 1989. Print.

Thomas, Vivian. The Moral Universe of Shakespeare's Problem Plays. NJ: Barnes \& Noble Books, 1987. Print.

Tillyard, E.M. Shakespeare's Problem Plays. Toronto: Toronto University Press, 1971. Print.

Vickers, Brian. Shakespeare: The Critical Heritage. 1623-1692. Vol. 1. London1974. Print.

Waller, G. All's Well That Ends Well: New Critical Essays. New York: Routledge, 2007. Print.

Wheeler, R. P. Critical Essays on Shakespeare's Measure for Measure. G.K. Hall \& Co., 1999. Print. 
